REVIEW

\title{
Biologic targeting in the treatment of inflammatory bowel diseases
}

\author{
Matteo Bosani \\ Sandro Ardizzone \\ Gabriele Bianchi Porro \\ Chair of Gastroenterology, "L. Sacco” \\ University Hospital, Milan, Italy
}

\begin{abstract}
The etiology of inflammatory bowel disease (IBD) has not yet been clarified and immunosuppressive agents which nonspecifically reduce inflammation and immunity have been used in the conventional therapies for IBD. Evidence indicates that a dysregulation of mucosal immunity in the gut of IBD causes an overproduction of inflammatory cytokines and trafficking of effector leukocytes into the bowel, thus leading to an uncontrolled intestinal inflammation. Under normal situations, the intestinal mucosa is in a state of "controlled" inflammation regulated by a delicate balance of proinflammatory (tumor necrosis factor [TNF- $\alpha$ ], interferon-gamma [IFN- $\gamma$ ], interleukin-1 [IL-1], IL-6, IL-12 and anti-inflammatory cytokines IL-4, IL-10, IL-11). The mucosal immune system is the central effector of intestinal inflammation and injury, with cytokines playing a central role in modulating inflammation. Cytokines may therefore be a logical target for inflammatory bowel disease therapy using specific cytokine inhibitors. Biotechnology agents targeted against TNF, leukocyte adhesion, Th1 polarization, $\mathrm{T}$ cell activation, nuclear factor-kappaB (NF- $\mathrm{kB}$ ), and other miscellaneous therapies are being evaluated as potential therapies for the treatment of inflammatory bowel disease. In this context, infliximab and adalimumab are currently the only biologic agents approved in Europe for the treatment of inflammatory Crohn's disease. Other anti-TNF biologic agents have emerged, including CDP571, certolizumab pegol, etanercept, onercept. However, ongoing research continues to generate new biologic agents targeted at specific pathogenic mechanism involved in the inflammatory process. Lymphocyte-endothelial interactions mediated by adhesion molecules are important in leukocyte migration and recruitment to sites of inflammation, and selective blockade of these adhesion molecules is a novel and promising strategy to treat Crohn's disease. Therapeutics agents to inhibit leukocyte trafficking include natalizumab (approved for use in Crohn's disease in USA), MLN-02, and ISIS 2302. Other agents being investigated for the treatment of Crohn's disease include inhibitors of $\mathrm{T}$ cell activation, proinflammatory cytokine receptors, Th1 polarization, growth hormone, and growth factors. Agents being investigated for treatment of ulcerative colitis include many of those mentioned above. Controlled clinical trials are currently being conducted, exploring the safety and efficacy of old and new biologic agents, and the search certainly will open new and exciting perspective on the development of therapies for inflammatory bowel disease. A review is made of the main areas of research exploring the mechanisms associated with the pathogenesis of IBD, providing advances in the agents currently in use, and identifying a host of new therapeutic biologic targets.
\end{abstract}

Keywords: Crohn's disease, ulcerative colitis, biological therapy

\section{Introduction}

Inflammatory bowel diseases (IBD) are chronically relapsing intestinal inflammatory conditions with a typical onset in young adulthood and with an unpredictable disease course that may lead to debilitating complications. Crohn's disease (CD) and ulcerative colitis (UC) are two main phenotypes of IBD. ${ }^{1}$ Their etiopathogenesis has not been clearly elucidated but is thought to involve a complex interplay among genetic, environmental, microbial and immune factors. Thus, a more integrated 
approach (including different disciplines such as molecular microbiology, immunophysiology, and psychoneuroimmunology) may provide a more complete understanding of the IBD's pathogenesis.

Lifelong pharmacotherapy has remained the cornerstone of IBD management, whereas surgery has been relegated to treatment of refractory disease or specific complications.

Current guidelines about conventional IBD therapy recommend use of. aminosalicylates (sulphasalazine, 5-aminosalicylic acid), corticosteroids, immunosuppressive drugs (azathioprine [AZA], 6-mercaptopurine [6-MP], methotrexate [MTX], cyclosporin A [CyA]), the selection of which depends on the clinical goal (induction or remissionmaintenance), extent and severity of disease, response to current or prior treatment, and the presence of complications. ${ }^{2}$ Aminosalicylates are considered first-line therapy for mild to moderate UC and $\mathrm{CD}$; although effective in UC, inducing remission in $40 \%$ to $80 \%$ of patients, with $54 \%$ to $88 \%$ remaining in long-term remission, ${ }^{3}$ their efficacy is more controversial in CD. ${ }^{4-6}$ The therapeutic efficacy of 5-ASA may depend on the mucosal concentration. Combining topical and oral therapy can increase mucosal concentration 100-fold, which is more effective in refractory UC. A new delivery system also controls the colonic release of 5-ASA through a multi-matrix (MMX) of hydrophilic polymer and lipophilic excipients enclosed in a coated tablet (SPD-476). This may enhance mucosal delivery to the sigmoid colon.

Corticosteroids are indicated for moderate to severe UC or $\mathrm{CD}$ or for patients who do not respond to first-line therapy and provide response rates of $45 \%$ to $90 \%$ in UC and $60 \%$ to $78 \%$ in $\mathrm{CD} .{ }^{7}$ Corticosteroids suppress active inflammation in the acute setting, but they are ineffective maintenance agents with a side-effect profile that does not allow long-term treatment and they can have a high relapse rate. Moreover, most patients lose response to steroids over time. In addition, one year after starting corticosteroids, only $48 \%$ of UC and $32 \%$ of CD patients are corticosteroid-free without surgery, ${ }^{8}$ which underscores the importance of maintenance therapy after a steroid-induced remission.

Thiopurines (AZA, 6-MP) are effective maintenance immunosuppressant agents indicated for steroid-dependent patients $^{9-12}$ or after a cyclosporine-induced remission, ${ }^{13}$ but are limited by their slow onset of action and potential serious adverse events and toxicity ${ }^{14}$ (mostly toxic hepatitis, pancreatitis and lymphopenia, opportunistic infections).

CyA is a more rapidly acting therapeutic option for severe $\mathrm{UC}$ and $\mathrm{CD}^{15}$ refractory to conventional therapy; however, its use is restricted to experienced centers equipped to monitor blood levels because it is associated with significant and potential risks of hypertension, nephrotoxicity, electrolyte imbalance, encephalopathy, tremors, myelosuppression, opportunistic infections, and seizures. ${ }^{2}$ The current guidelines advice continuing AZA/6MP therapy during pregnancy because some studies showed no incidence difference in miscarriage, preterm delivery, low birth weight, or fetal malformation.

MTX has been established as an inductive agent for steroid-dependent CD (remission rate 39.4\%) and for mainteinance of remission after successful induction $(65 \%$ relapse-free after 40 weeks). ${ }^{16-17}$

However, MTX can produce potential myelosuppression, hepatotoxicity, and teratogenic and abortigenic effects.

In the last decade the management of refractory IBD has been changed dramatically by the advent of biologic therapies. The novel biologic agents, created with genetic technology and directed against a specific inflammatory mediator, have found some of their first real clinical applications in the treatment of IBD. A better understanding of mucosal immune pathology in Crohn's disease and the insights in the effect of gut mucosal cytokines and their importance in the inflammatory process have led to the development of new therapies with selective targets in the immune pathway. ${ }^{18-20}$

We review the main areas of research and explore the mechanisms more intimately associated with the development of IBD, identifying a host of new therapeutic agents potentially interacting with or interrupting specific targets in the pathogenesis of IBD (Tables 1 and 2).

Moreover, some guidelines summarizing the recommendations for use of biologics agents in the clinical practice will be provided.

\section{Pathogenetic background Genetic factors}

IBD is now thought to represent a chronic disease characterized by a diffuse inflammation of the intestinal mucosa associated with a dysregulation of the mucosal immune system, and an inappropriate response of the intestinal mucosal immune system to otherwise innocuous luminal antigens in a genetically susceptible host. ${ }^{21}$

Although CD and UC are considered to be an adaptive disease driven by the immune system, the quest for IBD-related genes has indicated that in some patients, deficiencies in the innate immune response can be linked to the development of IBD.

Genetic variations in the genes that play a role in the innate and adaptative immune systems are the result of an everlasting arms race between the human species and its environment. 
Table I Therapeutic targets and biologic agents

\begin{tabular}{|c|c|c|}
\hline Target & Biologic agents & Phase of investigation \\
\hline Inhibitors of T cell activation & Anti-CD40 ligand & Phase II \\
\hline Anti-CD4 therapy & CM-T4I2, MAX.16H5, B-F5 & Discontinued \\
\hline Anti-CD3 & Visulizumab & Phase III suspended \\
\hline \multirow[t]{2}{*}{ Anti-inflammatory cytokines } & IL-I0 & Failed phase II/III \\
\hline & IL-II & Phase II \\
\hline \multicolumn{3}{|l|}{ Inhibitors of proinflammatory cytokines } \\
\hline \multirow[t]{7}{*}{ TNF- $\alpha$ blockers } & Anti-TNF therapies: Infliximab CDP57I & Phase IV \\
\hline & Certolizumab pegol & Failed phase III/Ila \\
\hline & RDP58 & Phase III/IIlb \\
\hline & Etanercept & Phase II \\
\hline & Onercept & Failed phase II \\
\hline & Adalimumab & Failed phase II \\
\hline & & Phase IV \\
\hline Inhibitors of proinflamatory cytokine receptor & Anti-IL-6R & Phase II \\
\hline \multirow[t]{4}{*}{ Inhibitors of Th I polarization } & Anti-IL-2 receptor antibodies & Phase II \\
\hline & (daclizumab, basiliximab), & \\
\hline & Anti-IL-I2 & Phase II \\
\hline & Anti-IFN- $\gamma$ (fontolizumab) & Phase II \\
\hline \multirow[t]{3}{*}{ Adhesion molecule inhibitors } & Natalizumab & Phase IV ( only in USA) \\
\hline & MLN-02 & Phase III \\
\hline & ISIS 2302 & Failed phase III/Phase II \\
\hline \multirow[t]{4}{*}{ Growth hormone an growth factors } & Human growth hormone, Epidermal & Phase II \\
\hline & growth factor Sargramostin & Phase II \\
\hline & Filgrastim & Phase III \\
\hline & & Phase Ila \\
\hline
\end{tabular}

Abbreviations: TNF, tumor necrosis factor; IL, interleukin; MLN-02, $\alpha_{4} \beta_{7}$ integrin antibody; ISIS 2302, antisense oligonucleotide to intercellular adhesion molecule I; Th, T helper cell; IFN, interferon.

There is ample evidence that IBD are, in part, the result of a genetic predisposition, with multiple susceptibility genes, some common to both diseases and some linked separately to one disease or the other. Recently, a gene conferring susceptibility to $\mathrm{CD}$ was identified by genome-wide screening, on chromosome 16 in families with several affected members. ${ }^{22,23}$

The gene, known as NOD2/CARD15, is similar to the $\mathrm{R}$ factor genes of plants conferring resistance to infection, and was designed as IBDI locus. Mutations of the NOD2/CARD15 gene in this region have been conclusively associated with CD. NOD proteins are thought to be cytosolic receptors for pathogenic bacterial signals; NOD2 is expressed in monocytes and activates nuclear factor kappaB (NF- $\mathrm{KB})$, which is a key transcriptional factor involved in the onset of immunoinflammatory responses..$^{24,25}$ However, there are controversial results in experimental studies about the relationship between mutated NOD2 and activation of
NF- $\kappa \mathrm{B}$ (decrease or increase), depending on the experimental settings. Mutations are no more frequent in patients with $\mathrm{UC}$ than in controls, supporting the theory that $\mathrm{CD}$ and $\mathrm{UC}$ are related, but different, disorders. As far as the modes by which the NOD2/CARD15 confers susceptibility to CD are concerned, two hypotheses have been advanced based on the molecular domains of the molecule. One is that the presence of the caspase activation and recognition domains indicates that NOD2/CARD15 plays a role in apoptosis. ${ }^{26}$

The other is that the presence of the leucine-rich repeat domain indicates that the NOD2/CARD15 protein has a role in the recognition of microbes and innate immunity, because regions of leucine-rich repeat are a feature of the proteins that identify molecular patterns of microbial products, the so-called pattern-recognition receptors. Thus the NOD proteins may represent another family of pattern-recognition receptors, in that NOD1 and NOD2 bind endotoxins intracellularly, resulting in activation of the transcription factor NF- $\mathrm{KB}$, 
which, in turn, activates the production on inflammatory cytokines. NF- $\kappa \mathrm{B}$ is increased in the lesions of $\mathrm{CD}$, as are numerous inflammatory cytokines whose transcription is mediated by NF- $\kappa \mathrm{B}$, including tumor necrosis factor alpha (TNF- $\alpha$ ), interleukin-1 (IL-1), IL-6, and IL-12. Multiple receptors are linked to the $\mathrm{NF}-\kappa \mathrm{B}$ signal-transduction pathway, such as those for the inflammatory cytokines IL-1 and TNF- $\alpha$, which have a major role in $\mathrm{CD}$, the toll-like receptors (TLRs), and NOD2. Thus, NF- $\mathrm{KB}$ is a final common pathway for a number of inflammatory signals, and its inhibition is a rationale target for drug therapy. Moreover, any understanding of the contributions of NOD2/CARD15 mutations to the development of CD would be not useful without a determination of which specific features or clusters of features of the disease are referred to as phenotypes.

Recently several more IBD susceptibility gene have been identified. A widely replicated associated locus is the IBD5 locus on chromosome 5q31-q33 encoding for the organic cation transporters 1 and 2: unfortunately, the causative IBD susceptibility gene from this region has not yet been unequivocally identified. A recent genome-wide association scan identified a coding single nucleotide polymorphism (SNP), within the autophagy-related 16-like 1 gene (ATG16L1) on chromosome 2q37.1, to be strongly associated with CD. Finally, a genome-wide association study found that genetic variation in the interleukin 23 receptor gene (IL23R) has a protective effect for developing CD. ${ }^{27}$

\section{Environmental factors}

The importance of environmental factors is supported by the striking increase in the frequency of CD in the moredeveloped world over the past 50 years, and the increased recognition of the disease, with progressive industrialization in less developed countries. Elements within a changing environment that might affect development of the mucosal immune system, the enteric microflora, or both, include improved hygiene, consumption of sterile and nonfermented foods, vaccination, and age at first exposure to intestinal pathogens. ${ }^{28}$ During the last few years, with improvements in the socioeconomic conditions of the developing world, the IBD incidence is increasing. In the attempt to offer an explanation for temporal changes in disease frequency and the high prevalence of genes that predispose individuals to $\mathrm{CD}$, it is suggested that the same genes confer selective advantage, such as mucosal immunoprotection in an unsanitary world. The effects of poor hygiene at early childhood are diverse. In some situations, poor hygiene can lead to increased pathogenic infections, but in others, it results in a higher exposure to harmless microorganisms and priming of the regulatory immune system, thus lowering the risk for development of IBD. With a changing environment and lifestyle in an industrialized society, this advantage ceases and becomes a liability since it is associated with a greater mucosal immune responsiveness as well as the risk of progression from physiological to pathological mucosal inflammation. The decrease in infections from helminthic parasites in the developed world is one aspect of this environmental hypothesis, and has been mechanistically associated with the rise in prevalence of CD. ${ }^{29}$ Helminths are associated with a type-2 helper T cell response (Th2), which would counterbalance the type- 1 helper $\mathrm{T}$ cell response (Th1) of CD. The effects of poor hygiene are diverse. In some situations, poor hygiene can lead to increased pathogenic infections, but in others, it results in a higher exposure to harmless microorganisms and priming of the regulatory immune system, thus lowering the risk for development of IBD.

Other environmental factors could affect the disease phenotype. The effect of cigarette smoking or the opposite effect of this condition on the outcome of each form of IBD represents the most intriguing connection between environmental factors and IBD. Most reports have shown that no smoking is a feature of patients with UC, whereas smoking is a feature of patients with CD. ${ }^{30,31}$ Cigarette smoking has been shown to affect cellular and humoral immunity, ${ }^{32,33}$ and to increase colonic mucus production; ${ }^{34}$ whilst both smoking and nicotine ${ }^{35}$ have been shown to reduce colonic motility. Finally, results from in vivo studies have shown that nicotine also has an inhibitory effect on Th2 function, which predominates in UC, but has no effect on Th-1 cells, that are predominant in $\mathrm{CD} .{ }^{36}$

Increased intestinal permeability may play a role in the pathogenesis of CD. A leaky intestinal barrier intensifies antigen absorption, which, in turn, leads to an exaggerated immune stimulation, perpetuating the inflammatory process, ${ }^{37}$ reflected at the systemic level by an excessive number of mature B cells. ${ }^{19}$ During inflammation cytoprotective factors, including transforming growth factor-alpha (TGF- $\alpha$ ), TGF- $\beta$, epidermal growth factor (EGF), keratinocyte growth factor (KGF), IL-11, and growth hormone, are released into intestinal mucosa to restore the integrity of the epithelial cell barrier and promote epithelial restitution and repair. ${ }^{38}$

\section{Microbial factors}

Microbial agents appear to be intimately involved in the pathogenesis of IBD. Although available data do not convincingly incriminate a single, persistent pathogen as a universal 
cause of IBD, this hypothesis should still be considered in view of the possibility that these disorders may represent a heterogeneous group of diseases with multiple etiologies.

During the last few years Mycobacteria paratuberculosis, and measles virus, as well as Listeria monocytogenes have been implicated. ${ }^{18,19,28}$ However, despite extensive investigations on these and other organisms over the past four decades, no single specific infection has convincingly been shown to be critical to the pathogenesis of IBD.

The possibility that components of the normal intestinal flora could trigger, initiate, or somehow contribute to IBD is another unknown factor. Bacteria within the enteric lumen have a complex open ecosystem that is continuous with the external environment, and there are up to ten times more bacteria than there are cells in the human body. Differences in microbial ecology in individuals with UC and CD and normal individuals were not strongly supported by early investigations, but more recently, a significant decrease in the number of anaerobic bacteria and Lactobacillus in patients with active, but not inactive, IBD has been found. ${ }^{39}$ Moreover, evidence of a relationship between colonic microflora and the pathogenesis of UC comes from studies on genetically engineered animals that develop colitis when exposed to nonpathogenic colonic bacterial microflora in an environment free from specific pathogens, but not when they are in a sterile germ-free environment.

It is reasonable to consider therapeutic approaches that eliminate the bacterial antigens and adjuvants that constantly drive the pathogenic immune response as a potentially important component in treating IBD, in concert with anti-inflammatory and immunosuppressants agents. Use of narrow- and broadspectrum antibiotics, probiotics (beneficial bacteria), prebiotics (dietary components that foster the growth of beneficial bacteria), or the combination of each of these approaches has considerable logic, but at the moment are supported by few controlled studies.

This complex interplay of genetic, microbial, and environmental factors culminates in a sustained activation of the mucosal immune and nonimmune response, likely facilitated by defects in the intestinal epithelial barrier and mucosal immune system, resulting in active chronic inflammation and tissue damage.

\section{Immuno-inflammatory factors $\mathrm{CD} 4^{+}$cells and T-helper subsets}

Under normal conditions, the intestinal mucosa is in a state of "controlled" inflammation regulated by a delicate balance of proinflammatory and anti-inflammatory cytokines.
The uncontrolled inflammatory reaction in IBD probably results from interplay between genetic deficiencies in the innate immune system and an exaggerated $\mathrm{T}$ cell-driven adaptive immune response. The crucial role of $\mathrm{CD} 4^{+} \mathrm{T}$ cells in the inflammatory cascade underlying IBD has been well established. Activation of these T cells is a multi-step process involving strict control by cytokines and membrane-bound cellular interaction.

Upon encountering an initiating antigen from an antigenpresenting cell (APC), mucosal lymphocytes are activated to secrete IFN- $\gamma$ and IL-2.

$\mathrm{CD}^{+} \mathrm{T}$ cells regulate critical aspects of the specific immune response. $\mathrm{CD}^{+} \mathrm{T}$ cells have been classified as either Th1 or Th2 and the new Th17 (T helper 17), on the basis of function and according to their ability to elaborate specific cytokines. Th1 cells orchestrate cell mediated immune responses and are characterized by their ability to secrete IL-2, INF- $\gamma$, and TNF- $\beta$. IL-2 promotes the clonal expansion of T cells and enhances the function of T and B cells. INF- $\gamma$ activates APCs and macrophages to produce IL-12, thereby driving Th1 cells producing even larger amounts of INF- $\gamma$, IL- 2 , and TNF- $\beta$.

Th2 cells, in contrast, mediate humoral responses and secrete IL-4, IL-5, IL-6, IL-10, and IL-13. These subsets regulate each other reciprocally through key cytokines. IFN- $\gamma$, produced by Th1 cells, suppresses the development of Th2, whereas IL-4, IL-10, and IL-13 secreted by Th2 cells inhibit Th1 responses. ${ }^{19-40}$ The Th17 lineage has emerged from discovery of a new family of cytokines (IL-17 family) and identification of new activities for the pleiotropic cytokines, TGF, and IL-6. Th17 cells appear to have evolved as an arm of the adaptative immune system specialized for enhanced host protection against extracellular bacteria and some fungi or microbes probably not well covered by $\mathrm{Th} 1$ or $\mathrm{Th} 2$ immunity.

$\mathrm{CD}$ is associated with type 1 helper $\mathrm{T}$ cell (Th1) cytokines, ${ }^{19,41}$ while UC cytokine patterns are less clear; UC does not fit clearly into the Th1/Th2 dichotomy but more closely resembles, at least in established disease, a modified Th2 response. ${ }^{40,41}$

Thus $\mathrm{CD}^{+} \mathrm{T}$ cells clearly play an important role in shaping the immune response, and the inhibition of Th1 responses could represent a significant goal in the treatment of IBD, especially of $\mathrm{CD}$ where the evidence of the Th1 effects is strongest.

Moreover, the main abnormality responsible for leading to inflammation is now known to be an exaggerated $\mathrm{T}$ cell response causing mucosal hyper-responsiveness to commensal bacteria. $^{42}$

Cross-reactivity of peripheral-blood and coloniclamina-propria $\mathrm{CD}^{+} \mathrm{T}$ cells with indigenous flora (bacteroides, 
bifidobacteria, and various enterobacteria) in patients with $\mathrm{CD}$ and UC suggests that abnormal T cell-specific immune responses to host flora are important in their pathogenesis. ${ }^{43}$

Intestinal Th1 activation and cytokine release is associated with the generation of activated matrix metalloproteinases which are essential mediators of tissue destruction. ${ }^{44,45}$

At least two mechanisms regulate activated mucosal $\mathrm{T}$ cells. The first is based on the function of both the effector and regulator $T$ cell subpopulations within the healthy mucosa; effector $\mathrm{T}$ cells are capable of causing intestinal inflammation, and regulatory $\mathrm{T}$ cells are able to control or prevent inflammation. ${ }^{46}$

The second mechanism consists of end of immune responses by apoptosis induction in activated $\mathrm{T}$ cells once pathogens have been dealt with. In $\mathrm{CD}$ patients, mucosal $\mathrm{T}$ cells are resistant to apoptosis, which leads to accumulation of $\mathrm{T}$ cells and persistence of the inflammatory response. ${ }^{47,48}$ In UC patients, $\mathrm{T}$ cells in the lamina propria are more susceptible to Fas-mediated apoptosis. ${ }^{49}$ Furthermore, the Fas ligand (FasL) is strongly expressed by $\mathrm{T}$ cells in active UC but not in CD lesions, suggesting that Fas-FasL induced apoptosis plays a part in the mucosal damage of UC. ${ }^{50}$

\section{Anti-inflammatory cytokines}

\section{IL-IO}

IL-10 is an antiinflammatory cytokine produced by $\mathrm{T}$ cells, B cells and monocyte-activated lipopolysaccharides. When the body is presented with an antigen, IL-10 inhibits the production of IL- $1 \alpha$, IL- 6 , and TNF- $\alpha$. Thus, it contributes to downregulation of acute inflammatory responses. In animal models, IL-10 maintains immune homeostasis in the gut and may play a role in the treatment of CD. ${ }^{51}$

\section{IL-I I}

IL-11 is a novel cytokine derived from mesenchymal cells. It has potent thrombocytopoietic properties and is used as a treatment for thrombocytopenia in cancer chemotherapy. ${ }^{52}$ The evaluation of IL-11 for use in CD stems from data showing the positive effects of this cytokine on the mucosal barrier function. IL-11 attenuates the inflammatory response by inhibiting expression of NF- $\kappa \mathrm{B}$ and in turn IL-1, TNF- $\alpha$, and other proinflammatory peptides. ${ }^{53}$

Incidental findings of improved intestinal mucosal integrity in models of colitis injury ${ }^{54}$ led to studies of IL-11 on animal models of colitis, in which a benefit was observed. ${ }^{55,56}$

\section{ThI polarization}

\section{IL-2}

IL-2 is a critical cofactor for the initiation and continuation of a specific immune response. IL-2 is produced by native $\mathrm{T}$ cells after activation. At the same time, activated $\mathrm{T}$ cells elaborate IL-2 receptor, completing an autocrine and paracrine loop-promoting clonal expansion. IL-2 has important effects on other immune cells, including B cells, monocytes, and natural killer (NK) cells. ${ }^{18,19,57}$

\section{IFN- $\gamma$}

IFN- $\gamma$ is elevated in all genetic animal models of IBD and seems to be critical in the development of Th1 responses. If the target of IBD therapy is to reduce Th1 responses, then direct neutralization of IFN- $\gamma$ is a rational approach. Surprisingly, anti-IFN- $\gamma$ administered to IL-10 knock-out mice showed no benefit. It is also demonstrated in experimental induced colitis that ablation of IFN- $\gamma$ gene in $\mathrm{T}$ cells does not prevent the disease. ${ }^{18,19,57}$

\section{IL-12/IL- I7/IL-23}

IL-23 is a heterodimeric cytokine composed of a p19 subunit and the $\mathrm{p} 40$ subunit of IL-12. It is produced by macrophages and dendritic cells, and activates memory T cells. IL-12 is composed of p35 and p40 subunits and acts as an important factor for the differentiation of naive $\mathrm{T}$ cells into $\mathrm{T}$-helper type $1 \mathrm{CD}^{+}$lymphocytes secreting IFN- $\gamma$. Therefore it has been reported that IL-12 is crucial for $\mathrm{T}$ cell-dependent immune and inflammatory responses through the use of IL-12 p40 gene-targeted mice and neutralizing antibodies against p40. Apparently IL-12 is a key factor driving Th1 responses and IFN production in the initial phases of an immune response, but conversely IL-12 may play a subsequent immunoregulatory role in late-stage inflammation at a point when IL-23 strongly supports the inflammatory process. IL-23 induces the production of IL-17 by a unique subset of memory T cells. IL-17 is known to stimulate fibroblasts, endothelial cells, macrophages, and epithelial cells to secrete multiple proinflammatory mediators and the local production of IL-17 causes site-specific activation of inflammatory cells. Dendritic cells found in the lamina propria of the small intestine were described as constitutively expressing IL-23, whereas IL-23 regulates a highly potent $\mathrm{T}$ cell-derived cytokine that has major actions on the immune system. IL-23 specifically stimulates memory $\mathrm{CD}^{+} \mathrm{T}$ cells contrasting the IL-12 which is a stimulant for naive $\mathrm{CD}^{+} \mathrm{T}$ cells. Studies with IL-23 deficient mice show that IL-23 is essential for the manifestation of intestinal 
inflammation and a dominant role for IL-23 over IL-12 in central nervous system and joint autoimmune inflammation has been described. These findings point to IL-23, but not IL-12, as the necessary mediator for organ specific autoimmune diseases development. ${ }^{18,19,57-59}$

\section{IL-I8}

IL-18 is a recently described cytokine that mainly exists in activated macrophages and epithelial cells and shares biological activities with IL-12 in driving the development of Th1 by inducing IFN- $\gamma$. IL-18 is upregulated in the intestinal mucosal cells of patients with IBD $^{60}$ and animal models have shown benefit of anti-IL-18 antibodies in reducing the severity of colitis. ${ }^{61}$

\section{Proinflammatory cytokines \\ IL-I and TNF- $\alpha$}

IL-1 and TNF- $\alpha$ share a multitude of proinflammatory properties and appear to be critical to the amplification of mucosal inflammation in IBD. Both cytokines are primarily secreted by monocytes and macrophages upon activation, and induce intestinal macrophages, neutrophils, fibroblasts, and smooth-muscle cells to elaborate prostaglandins, proteases, and other soluble mediators of inflammation and injury, as well as other inflammatory and chemotactic cytokines. An enhanced expression of IL-1 and TNF was found in IBD, and the important role of TNF was also confirmed in the genesis of these diseases. The effects of TNF in the intestine which may play a role in mucosal inflammation are disruption of the epithelial barrier, induction of apoptosis of the villous epithelial cells and secretion of chemokines from the intestinal epithelial cells. TNF activates endothelium by upregulating E-selectin and other adhesion molecules such as intercellular adhesion molecule-1 (ICAM-1) as well as by inducing the expression of cytokines and chemokines. TNF also activates neutrophils and macrophages and stimulates B cells. It increases the production of IFN- $\gamma$ by mucosal T cells independently of IL-12 and IL-18.

It activates CD44 in T cells and enhances intraepithelial lymphocyte proliferation and migration. TNF also stimulates stromal cells from the fetal gut to produce matrix metalloproteinases (MMPs), which could lead to tissue injury, mobilizes dendritic cells from the intestine and appears to be a determinant in granuloma formation, ${ }^{66}$ and in association with IL-6, IL-1 may contribute to the constitutional symptoms of IBD and lead to the generation of acute phase proteins. ${ }^{62}$

TNF- $\alpha$ is translated as a precursor protein which contains an unusually long signal peptide that anchors the protein to the outer membrane. During local and systemic inflammatory reactions, membrane bound TNF- $\alpha$ is cleaved extracellularly by a specific zinc-dependent metalloprotease that has been designated TNF- $\alpha$ converting enzyme (TACE), yielding the soluble homotrimeric form of TNF- $\alpha$ that can act either as a compartmentalized or circulating cytokine.

It was initially thought that cleavage of TNF- $\alpha$ constituted a major final road block for TNF- $\alpha$ production but subsequently it was recognized that membrane expressed TNF- $\alpha$ is biologically active as a homotrimer during cell-cell contact by interacting with both p55 and p75 TNF receptors. ${ }^{67,68} \mathrm{TACE}$ is member of the ADAM (a disintegrin and metalloproteinase) family of cell surface proteases, which are induced during inflammation. ${ }^{69,70}$

Potential sites for therapeutic manipulation along TNF production, processing, and secretion pathway are shown in Figure 1.

\section{IL-6}

IL-6 is a pleiotropic cytokine with a central role in immune regulation, inflammation, and hematopoiesis. ${ }^{71}$ Increased serum concentrations of IL-6 and soluble IL-6 receptor (IL-6R) have been correlated to clinical activity of CD, and animal models have strongly suggested the therapeutic potential of anti-IL-6R monoclonal antibody in CD. ${ }^{72,73}$

\section{Peroxisome proliferator-activated receptors}

Peroxisome proliferator-activated receptors (PPARs) are members of the nuclear hormone receptor superfamily of transcription factors whose activities are regulated by high affinity binding of small lipophilic ligands such as steroid hormones. $^{74}$

A new class of antidiabetic drugs, thiazolidinediones, has been developed that bind to the $\gamma$ subtype of the PPARs. Colonic epithelial cells express high levels of PPARs proteins, and have the ability to produce inflammatory cytokines that may contribute to the inflammatory process in $\mathrm{UC}^{75}$

\section{Adhesion molecules and leukocyte recruitment}

Lymphocyte infiltration into the intestinal tract in IBD is mostly mediated by intectation between $\alpha 4 \beta 7$ integrin expressed on lymphocyte and one of its specific ligand mucosal vascular addressin CAM-1 (MAdCAM-1), expressed on the endothelial cells of the microvasculature in the inflamed intestinal tract. Integrins form a large family of transmembrane proteins required for cell 


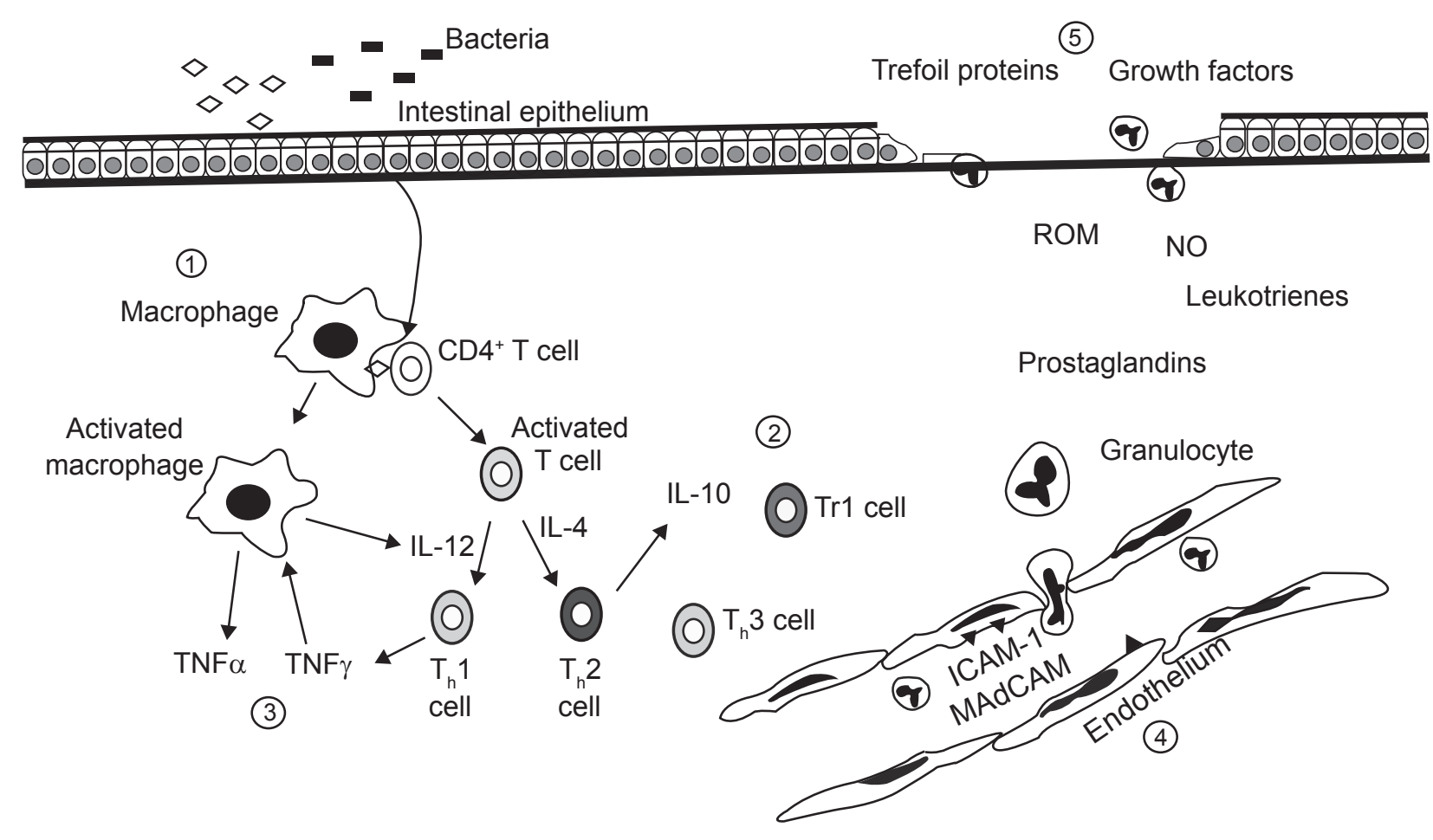

Figure I Activation pattern leading to TNF production and sites of potential TNF antagonism. Each activation pathway may vary depending on the cell type. The circled numbers show each step in TNF production and secretion pathway, which may be a potential target for therapeutic manipulation using specific inhibitors. Oxypentifylline and other type IV phosphodiesterase inhibitors interfere with gene expression at step I. Mesalazine inhibits TNF-mediated effects on intestinal epithelial cell proliferation at steps I and 2. Thalidomide enhances TNF mRNA degradation at step 6. The monoclonal antibodies infliximab CDP 57I and etanercept directly antagonize TNF binding to its membrane receptors at step 8 and 9 .

Abbreviations: AP-I, activator protein I; ERK, extracellular signal-regulated kinase; IV, intravenous; JNK, c-Jun N-terminal kinase; MAPK, mitogen-activated protein kinase; mTNF, membrane-anchored TNF precursor;TNF, tumor necrosis factor; sTNF, secreted TNF molecule;TACE,TNF-converting enzyme;TNFR-Fc, etanercept.

adhesion, attachment of the cell to the extracellular matrix, or to other cells and anchorage of the cytoskeleton to the plasma membrane. Alfa4 integrins are necessary not just for lymphocyte homing, but also for activation and signaling as well as interaction with extracellular matrix protein. In the pathogenesis of IBD, both T-lymphocyte migration into inflamed mucosa and local activation and proliferation contribute to the perpetuation of inflammation. Lymphocyte trafficking into the intestinal mucosa is a multi-step process mediated by three essential steps: rolling, adherence and transendothelial migration. ${ }^{76,77}$

Development of monoclonal antibodies against $\alpha 4$ integrin could permit the targeting of lymphocyte trafficking into the intestine as a novel therapeutic intervention.

Each of the pathogenic mechanisms elucidated above offers a potential target for novel therapeutic intervention.

Figure 2 illustrates the targets of biologic therapy.

\section{Definition of biologic therapy}

Biologic therapies encompass agents with diverse modes of action. They include: (1) native biologic preparations such as blood products and vaccines containing live, attenuated, or killed micro organisms; (2) recombinant peptides or proteins such as growth hormone, erythropoietin, and soon; (3) antibody-based therapy; (4) nucleic acidbased therapies; and (5) cell and gene therapy. ${ }^{78}$ At this time, the biotechnology therapies that are being used in clinical practice or investigated for the treatment of IBD are predominantly proteins, usually delivered intravenously or subcutaneously. The types of therapeutic proteins in use include recombinant human proteins with immunoregulatory effects, monoclonal antibodies (chimeric, humanized, and fully human), and fusions proteins. ${ }^{79}$ These small molecules can be screened for a specific activity against a specific targeted step in the pathogenesis of IBD (initiation, stimulation or perpetuation of mucosal inflammation).

Compared to the development of most compoundbased drugs, development of biologic agents has been relatively rapid. Biologic agents are often developed by selection of candidate peptides of identified physiologic function. 


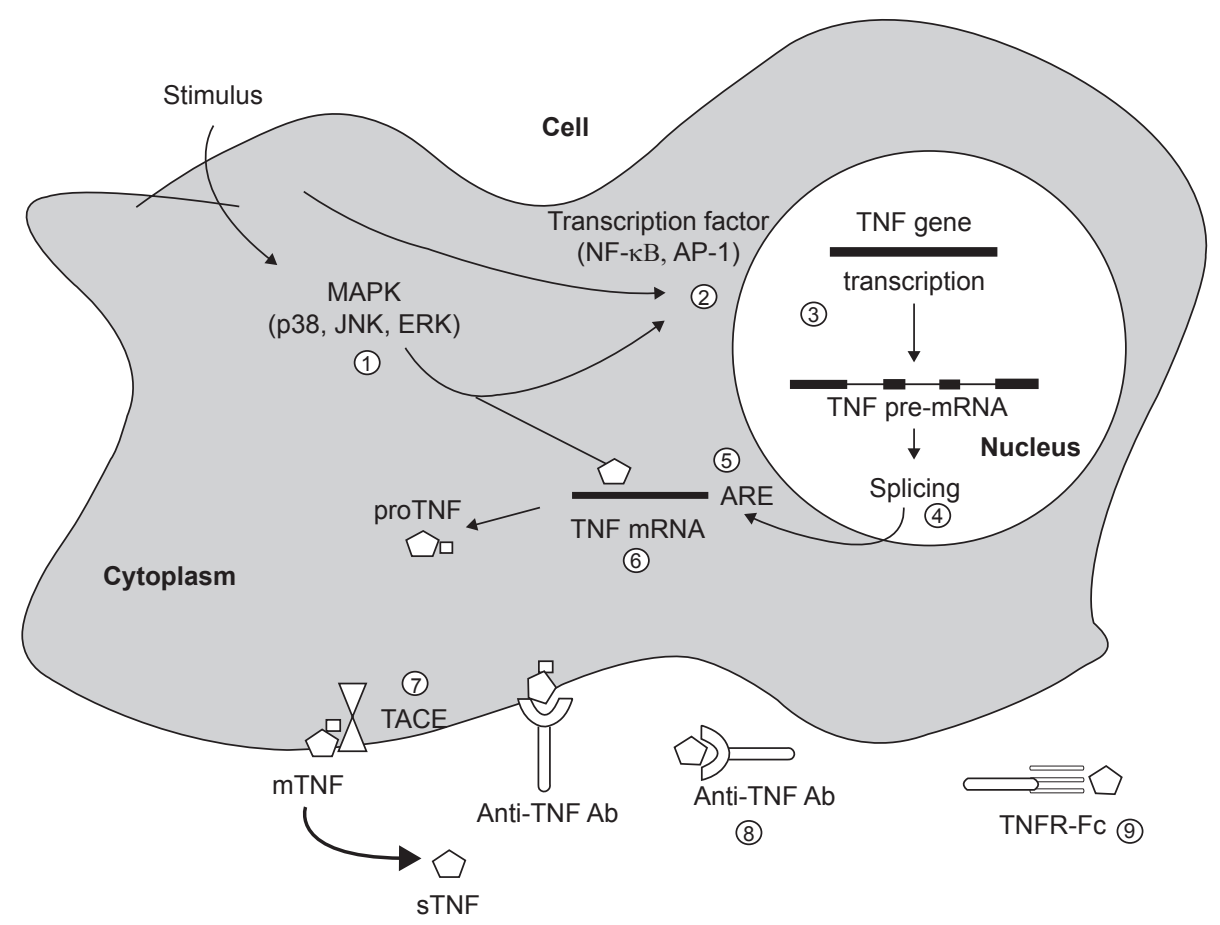

Figure 2 Overview of therapeutics targets for biologic agents in inflammatory bowel disease. They may be divided into the following areas: I) antigen and antigen presentation; 2) activation of effector T cells; 3) cytokine mediated response amplification;4) adhesion an recruitment; and 5) injury and repair. Copyright ( 2000 . Reproduced with permission from the American Gastroenterological Association. Papadakis CA, Targan SA. Tumor necrosis factor: biology and therapeutic inhibitors. Gastroenterology. 2000; I19:1148-1157.

Therefore, the time for preclinical development may be relatively short and potentially expensive.

\section{Manipulation of immunoinflammatory factors Inhibitors of $T$ cell activation CD40 ligand}

CD40 ligand (CD40L), expressed on T-lymphocytes after their interaction with an APC, is an important costimulatory molecule involved in $\mathrm{T}$ cell activation. CD40L binds CD40 (expressed on the APC) to stimulate the expression of yet another costimulatory molecule, B7 (on the APC membrane), which in turns binds to $\mathrm{CD} 28$ on the cell surface ${ }^{80}$ Inhibition of the cell activation by targeting these molecules is an attractive concept and a potential therapeutic intervention. A humanized monoclonal antibody to CD40L, IDEC-131, has been developed and a phase II trial initiated for CD. However, owing to concerns of thromboembolism, this trial has been halted. ${ }^{81}$ Recently a Italian study group demonstrated that engagement of CD40 in human intestinal fibroblast promoted the release of vascular EGF, IL-8, and hepatocyte growth factor. ${ }^{82}$ Thus, the CD40-CD40 ligand pathway appears to be crucially involved in regulating inflammation-driven angiogenesis, target of a potential therapeutic approach.

\section{Anti-CD4 antibodies}

Anti-CD4 antibodies have been used in a variety of autoimmune diseases, and have also been tested in CD and UC.

A CD4 depleting antibody (cM-T412) was tested in two open studies ${ }^{83,84}$ Both CD and UC patients achieved clinical and endoscopic improvement/remission after a period of treatment varying from seven to 11 days.

In another three open trials, ${ }^{85-87} \mathrm{CD} 4$ nondepleting antibodies (MAX.16H5 and B-F5) were administered to a total of $16 \mathrm{CD}$ and nine UC patients with active disease. Of the nine UC patients, five achieved remission versus only six of 16 CD patients. Thus, CD4 depleting antibodies seem to be more effective means of therapy than nondepleting antibodies. However, this mode of treatment was mostly associated with a significant decrease in CD4 cells, and because of concerns of CD4 lymphopenia, no further studies have been performed.

\section{Anti-CD3 antibodies}

Visilizumab (UhM291) is a humanized CD3 $\varepsilon$ chain of the $\mathrm{T}$ cell receptor expressed on activated T cells. Visilizumab 
Table 2 Comparison of compound-based drugs and biologic agents ${ }^{78}$

\begin{tabular}{|c|c|c|}
\hline & Compound-based drugs & Biologic agents \\
\hline Composition & "Small molecule" compound & Peptide, protein, RNA, DNA \\
\hline Route of administration & Oral, parenteral, topical & Typically parenteral \\
\hline Discovery and Development & $\begin{array}{l}\text { Usually by large-scale screening of } \\
\text { compound libraries to identify parent } \\
\text { drugs; chemical manipulation to alter } \\
\text { characteristics }\end{array}$ & $\begin{array}{l}\text { Choice of target defined by mechanism } \\
\text { of disease. Development often by } \\
\text { recombinant techniques }\end{array}$ \\
\hline Cost & $\begin{array}{l}\text { Expensive to develop, less expensive } \\
\text { to produce }\end{array}$ & $\begin{array}{l}\text { Relatively less expensive to develop, more } \\
\text { expensive to produce }\end{array}$ \\
\hline Time to clinical trial & Relatively long & Relatively brief \\
\hline Examples & $\begin{array}{l}\text { Classic receptor blockers, enzyme } \\
\text { inhibitors, corticosteroids, immune } \\
\text { modulators }\end{array}$ & $\begin{array}{l}\text { Recombinant cytokines, cytokine receptor } \\
\text { antagonists, chimeric and humanized } \\
\text { antibodies, antisense oligonucleotides, } \\
\text { somatic transgene vaccination }\end{array}$ \\
\hline
\end{tabular}

may induce activated $\mathrm{T}$ cell apoptosis and production of IL-10, a potent anti-inflammatory cytokine. ${ }^{88}$ In a phase I dose-escalation study, seven patients with severe steroidrefractory UC received two infusions of visilizumab $15 \mu \mathrm{g} / \mathrm{kg}$ one day apart. Data were available only for five patients, all achieving clinical and endoscopic remission that persisted for several months after treatment. Three of five patients discontinued steroid treatment. Adverse events encountered included transient decrease in $\mathrm{T}$ lymphocyte counts and cytokine-release symptoms. There were no infective complications. ${ }^{89}$ The phase I dose ranging study in UC patients has been reported, ${ }^{90}$ but sadly the phase III study was suspended in 2007 when interim analysis showed no benefit.

\section{Anti-inflammatory cytokines IL-10}

A dose-response, placebo-controlled study reported that therapy with recombinant IL-10 (rHuIL-10) at doses of $0.5,1,5,10$, or $25 \mu \mathrm{g} / \mathrm{Kg}$ intravenously for seven days was beneficial in 46 refractory CD patients. ${ }^{91}$ However, these encouraging preliminary results were not confirmed by three large placebo-controlled dose-response trials in patients with mild to moderately active or chronically active CD.

In the first, ${ }^{92} 329$ patients with $\mathrm{CD}$ refractory to treatment were given subcutaneous human recombinant (rhu) IL-10 1, 4, $8,20 \mu \mathrm{g} / \mathrm{kg}$ or placebo, for 28 days. No statistically significant difference was found between these treatment groups. However, a tendency toward clinical improvement but not remission was observed in the $8 \mu \mathrm{g} / \mathrm{kg}$ dose group. In the second trial, ${ }^{93}$ 95 patients with mild to moderately active CD were treated with subcutaneous (rhu) IL-10 1, 5, 10, $20 \mu \mathrm{g} / \mathrm{kg}$, or placebo for 28 days. At the end of the treatment, clinical remission and endoscopic improvement was achieved in $23.5 \%$ of patients receiving $5 \mu \mathrm{g} / \mathrm{kg}$ (rhu) IL-10 vs $0 \%$ of patients in the placebo group. In the last study, 373 patients with CD who required prednisone or prednisolone (15-25 $\mathrm{mg}$ /daily) to maintain CDAI $<150$ were treated with (rhu) IL-10 4, $8 \mu \mathrm{g} / \mathrm{kg}$, or placebo once daily subcutaneously for two weeks, then three times each week for 26 weeks. At end of 28 weeks of (rhu) IL-10 treatment, intention-to-treat analysis demonstrated no significant difference in the prednisone withdrawal and clinical remission rates between the different (rhu) IL-10 doses and placebo. ${ }^{94}$ Finally, a phase II placebo-controlled dose response trial of (rhu) IL-10 failed to show a beneficial effect in 94 patients with mild to moderately active UC. ${ }^{95}$

Development of systemic administration of (rhu) IL-10 by intravenous or subcutaneous routes for the indications of UC and $\mathrm{CD}$ has been discontinued because of a lack of efficacy in these controlled trials. Recent animal studies have suggested that local administration of IL-10 to the colon via genetically engineered lactococcus bacteria that are orally administered may result in high colonic mucosal concentrations of IL-10 and potentially enhanced efficacy. ${ }^{96}$ It is possible that this approach to IL-10 therapy will be an alternative IL-10 therapeutic approach for $\mathrm{UC}$ and $\mathrm{CD}$ patients.

\section{IL-I I}

Results of two clinical trials with recombinant human IL-11 (rhIL-11) in patients with CD have been reported thus far. In a placebo-controlled safety study in 76 patients with active CD, subcutaneously administered rhIL-11 was shown to be safe and well tolerated. ${ }^{97}$

In a second placebo-controlled study in 148 patients comparing two doses of subcutaneously administered rhIL-11, it was significantly superior in inducing remission after six weeks when compared to placebo, although the placebo 
rate was high (36.7\% vs $16.3 \%) .{ }^{98}$ The safety profile of this regimen appeared to be excellent, with only minor injection site reactions occurring more frequently among treated patients.

The efficacy of rhIL-11 was compared to prednisolone in patients with mild to moderate active CD (CDAI 220-400). In a double-blind, placebo-controlled trial, 51 patients were treated with rhIL-11 (1 mg/weekly) or prednisolone (starting dose $60 \mathrm{mg}$ /daily), for a 12-week follow-up period. At the end of the study, rhIL-11 and prednisolone induced long-term remission (12 weeks) in comparably sized subsets $(22 \%$ and $21 \%$, respectively) of patients with mild to moderate CD. ${ }^{99}$

\section{Inhibitors of proinflammatory cytokines TNF blockers \\ Infliximab}

Among the various biologic agents, infliximab has received the most attention, and is a biologic agent approved in the USA and Europe for the treatment of patients with moderate to severe $\mathrm{CD}$ unresponsive to conventional therapy or a full and adequate course of corticosteroids and immunosuppressive therapy, and to patients with actively draining fistulas. Recently it was approved also for the treatment of moderateto-severe UC refractory to conventional therapy.

Infliximab is a monoclonal chimeric antibody, targeting human TNF- $\alpha$, composed of a human constant region IgG1k light chain, accounting for approximately $75 \%$ of antibody, linked to a mouse variable region $(25 \%) .{ }^{57}$ Infliximab is known to bind soluble bioactive TNF in the intestinal mucosa and thereby neutrolize its effect. Infliximab also binds to membrane-bound TNF and leads to the in vitro destruction of immune cells by antibody-dependent cellular toxicity. Additionally, it has been shown to induce T cell apoptosis. ${ }^{64}$ Antagonism of membrane-bound TNF may be particularly important for the long term clinical effects of infliximab. Binding of infliximab to membrane-bound TNF on activated $\mathrm{T}$ cells has been shown to promote apoptotic T cell death. ${ }^{64}$

Initial open label studies, ${ }^{100,101}$ in which infliximab was effective in rapidly inducing clinical and endoscopic improvement/remission, have been confirmed in several controlled studies.

In the first randomized, placebo-controlled trial, 108 patients with moderate-to-severe CD which is resistant to conventional therapy, were treated with the single intravenous infusion of either placebo or infliximab at the dose of 5,10 , or $20 \mathrm{mg} / \mathrm{Kg}$. The rate of clinical response at four weeks were $81 \%$ for $5 \mathrm{mg} / \mathrm{kg}, 50 \%$ for $10 \mathrm{mg} / \mathrm{Kg}$ and $64 \%$ for $20 \mathrm{mg} / \mathrm{Kg}$, all of which were significantly higher than that for the placebo-treated group. A good result also for clinical remission at four weeks (33\% infliximab vs $4 \%$ placebo). ${ }^{102}$

Patients who maintained their response eight weeks after treatment (73/108 patients initially randomized) were re-randomized at week 12 to placebo or $10 \mathrm{mg} / \mathrm{kg}$ infliximab every eight weeks for four additional infusions. A trend toward significance was observed in the response at week 44 (eight weeks after the last infusion) in the infliximab-treated patients, compared with those receiving placebo. Quality of life was consistently better and serum C-reactive protein (CRP) levels were consistently lower in patients receiving infliximab. A significant difference was seen in the rate of remission at week 44 between infliximab and placebo group $(52.9 \%$ vs $20 \%, p=0.013)$. These data suggest that repeated dosing with infliximab may provide useful maintenance therapy, particularly in those patients initially achieving remission. ${ }^{103}$ The effectiveness of infliximab for the maintenance therapy for inflammatory CD was assessed in a large trial called ACCENT I. ${ }^{104}$ In this study 573 patients responders to a single infusion of infliximab $5 \mathrm{mg} / \mathrm{kg}$ were randomly assigned repeat infusions of placebo at weeks 2 and 6 and then every eight weeks thereafter until week 46 (group I), repeat infusions of $5 \mathrm{mg} / \mathrm{kg}$ infliximab at the same time-points (group II), or $5 \mathrm{mg} / \mathrm{kg}$ infliximab at weeks 2 and 6 followed by $10 \mathrm{mg} / \mathrm{kg}$ (group III). Three hundred and thirty-five patients (58\%) responded to a single infusion of infliximab within two weeks. At week 30, 23/110 (21\%) group I patients were in remission, compared with 44/113 (39\%) group II and 50/112 (45\%) group III.

Infliximab safety was consistent with that seen in other trials in $\mathrm{CD}$, and the incidence of serious infections was similar across treatment groups.

In addition, an analysis comparing the scheduled and episodic treatment strategies was conducted based on the ACCENT I data. The efficacy of the scheduled therapy was better than episodic strategy in terms of CDAI score, clinical remission and response rates, anti-infliximab antibodies production, improvement in IBDQ score, mucosal healing and CD-related hospitalization and surgery. ${ }^{105}$

For an evaluation of the infliximab maintenance therapy for fistulizing CD, ACCENT II trial was conducted. One hundred and ninety-six CD patients, with draining perianal and enterocutaneous fistulas who responded to the induction infliximab $5 \mathrm{mg} / \mathrm{kg}$ therapy (weeks $0,2,6$ ), received either placebo or infliximab at the same dose every eight weeks. The median time to the loss of response, response rate and complete fistula closure rate at week 54 in the infliximab 
maintenance group were significantly greater than those in the placebo group. ${ }^{106}$

However, reopening of fistulae is frequent, suggesting the persistence of deep fistula tracts despite superficial healing. Despite closure, most fistula tracts are still detectable at anal endosonography (AE), and the persistence of the internal tract is a condition at higher risk of fistula recurrence. For these reasons, regular AE or magnetic resonance evaluation may have an important role in defining patients with perianal fistulizing CD to be treated (or re-treated) with infliximab. Moreover, short-term regimen doses with infliximab and long-term treatment trials are necessary.

Initially, infliximab did not seem to have much therapeutic effect on UC. Two small pilot trials showed disappointing results for the drug in the treatment of refractory UC. ${ }^{107,108}$

Definitive evidence for the role of infliximab in the treatment of UC has been recently offered by the two large placebo-controlled clinical trials ACT 1 and ACT 2.

In the ACT 1 study, ${ }^{109} 364$ patients with active UC despite use of corticosteroids/AZA/6-MP, with endoscopic evidence of moderate or severe UC (endoscopy score $\geq 2$ ) and a total Mayo score of 6-12 inclusive, were randomized to receive placebo, infliximab $5 \mathrm{mg} / \mathrm{kg}$ or $10 \mathrm{mg} / \mathrm{kg}$ at weeks 0,2 , and 6 then every eight weeks through to week 46 . Significantly higher proportion of patients receiving infliximab $5 \mathrm{mg} / \mathrm{kg}$ $(64 \%)$ and $10 \mathrm{mg} / \mathrm{kg}(61.5 \%)$ had a clinical response at week 8 versus placebo-treated patients (37.2\%). At week 30 , $52.1 \%$ and $50.8 \%$ of infliximab-treated patients, respectively, achieved clinical response versus $29.8 \%$ of placebo-treated patients. At week 8, 38.8\% and $32.0 \%$ of infliximab 5- and $10 \mathrm{mg} / \mathrm{kg}$-treated patients, respectively, achieved clinical remission versus $14.9 \%$ of placebo-treated patients. These differences in remission rates persisted at week $30(33.9 \%$, $5 \mathrm{mg} / \mathrm{kg} ; 36.9 \%, 10 \mathrm{mg} / \mathrm{kg}$ versus $15.7 \%$, placebo). Mucosal healing was achieved at week 8 in $62 \%$ and $59 \%$ of patients receiving infliximab 5 and $10 \mathrm{mg} / \mathrm{kg}$, respectively, versus $33.9 \%$ of placebo-treated patients. This difference in mucosal healing was maintained at week $30(50.4 \%, 5 \mathrm{mg} / \mathrm{kg}, 49.2 \%$, $10 \mathrm{mg} / \mathrm{kg}$ versus $24.8 \%$ ). The proportion of patients who were able to discontinue corticosteroids while in clinical remission at week 30 was greater in the combined infliximab treatment group than in the placebo group (21.7\% versus $10.1 \%)$.

In the ACT 2 study, ${ }^{109} 364$ patients suffering from UC, refractory to at least one standard therapy including 5-ASA, corticosteroids or immunosuppressants, were randomized to receive infliximab $5 \mathrm{mg} / \mathrm{kg}$, infliximab $10 \mathrm{mg} / \mathrm{kg}$, or placebo at weeks $0,2,6,14$, and 22. Significantly more patients with infliximab $5 \mathrm{mg} / \mathrm{kg}(64.5 \%)$ and $10 \mathrm{mg} / \mathrm{kg}(69.2 \%)$ achieved clinical response at week 8 versus $29.3 \%$ who received placebo. At week $30,47.1 \%$ of patients receiving infliximab $5 \mathrm{mg} / \mathrm{kg}$ and $60 \%$ receiving $10 \mathrm{mg} / \mathrm{kg}$ were in clinical response versus $26 \%$ of patients receiving placebo. Clinical remission was performed at week 8 in $33.9 \%$ and $27.5 \%$ of infliximab 5 and $10 \mathrm{mg} / \mathrm{kg}$ patients, respectively, compared to $5.7 \%$ of placebo-treated patients. Differences in remission rates persisted at week $30(25.6 \%, 5 \mathrm{mg} / \mathrm{kg}$; $35.8 \%, 10 \mathrm{mg} / \mathrm{kg} ; 10.6 \%$, placebo). Mucosal healing was achieved at week 8 in $60.3 \%$ and $61.7 \%$ of patients receiving infliximab $5 \mathrm{mg} / \mathrm{kg}$ and $10 \mathrm{mg} / \mathrm{kg}$, respectively, compared to $30.9 \%$ of placebo-treated patients. Mucosal healing at week 30 was achieved in $46.3 \%$ and $56.7 \%$ of patients receiving infliximab $5 \mathrm{mg} / \mathrm{kg}$ and $10 \mathrm{mg} / \mathrm{kg}$, respectively, versus $30.1 \%$ of placebo-treated patients. The proportion of patients who were able to discontinue corticosteroids while in clinical remission at week 30 was significantly greater in both infliximab groups compared with the placebo group (18.3\%, $5 \mathrm{mg} / \mathrm{kg} ; 27.3 \%, 10 \mathrm{mg} / \mathrm{kg} ; 3.3 \%$ placebo).

In both trials, infliximab was well tolerated with a safety profile similar to that previously reported. Thus, in patients with moderate-to-severe UC, infliximab induces and maintains clinical response, clinical remission and mucosal healing, and permits the tapering of corticosteroids while maintaining remission.

Some studies and very few data are available for treatment of indeterminate colitis with infliximab. ${ }^{110,111}$ They suggested that patients with indeterminate colitis are more refractory to infliximab.

Many case reports and small series have been published on the use of infliximab for treating extraintestinal manifestations of IBD. Thus, infliximab has been reported to be effective in the treatment of pyoderma gangrenosum, ${ }^{112}$ uveitis and spondyloarthropathy associated with IBD. ${ }^{113,114}$

Recent data suggest that initial treatment of the disease with the combination of AZA and infliximab, a so called "top-down" approach, may be much more effective than the traditional step-up approach using the infliximab only in therapy-refractory CD. ${ }^{115}$

This study included $100 \mathrm{CD}$ patients with a CDAI greater than 220 who were never treated with steroids, immunomodulators, or infliximab. Patients were randomized to receive treatment with either three infliximab infusions (weeks 0 , $2,6)$ and AZA, topical budesonide ( $9 \mathrm{mg} /$ day), or systemic prednisone (40 mg/day), to be repeated as clinically necessary. In the top-down group, relapsing patients were given repeated infliximab and steroids when they failed to respond to infliximab. In the step-up group, infliximab was given 
only after failure of immunosuppression. For the top-down approach, a significantly higher remission rate at six months $(74.5 \%)$ was noted when compared with the step-up group (48.1\%). Top-down patients also did significantly better on endoscopic mucosal healing, steroid usage and development of fistulas. The success of the top-down approach cannot be accounted for by infliximab solely, as AZA was administered from the start as a maintenance treatment as well.

Although infliximab is well tolerated in the majority of patients, serious side effects may rarely occur, including serious infections (see below), drug-induced lupus acute infusion reactions, delayed hypersensitivity reactions, demyeliniation, possibly an increased risk of lymphoma, cardiac failure, and death. ${ }^{116,117}$ In clinical trials, infections requiring treatment occurred in $32 \%$ of infliximab-treated patients versus $22 \%$ of placebo-treated patients. There was no significant increase in serious infections or sepsis, but pneumonia, sepsis, miliary tuberculosis, and disseminated coccidiomycosis were all observed. In post-marketing surveillance, tuberculosis, histoplasmosis, listeriosis, aspergillosis, and pneumocystis pneumonia have all been observed, leading to death in some instances. As far as tuberculosis is concerned, reactivation of latent tuberculosis is a severe complication with all anti-TNF strategies. By February 2003, active tuberculosis was reported in 350 of more than 400,000 patients treated with infliximab or a cumulative incidence of 0.46 per 1000 patient-years. Most cases occurred within the first two months after initiation of therapy. The cumulative mortality amounted to $9 \%$. All patients who are candidate to a treatment with an anti-TNF agent should be evaluated for latent tuberculosis with a tuberculin test and chest X-ray. Treatment of latent tuberculosis should be initiated before therapy with infliximab.

The presence of murine elements in monoclonal antibodies is associated with a risk of immunogenicity. In a prospective study of 125 infliximab-treated patients, $61 \%$ of patients developed antibodies to infliximab (ATI, formerly called HACA) after the fifth infusion. ${ }^{118,119}$ These ATI were clearly associated with infusions reactions and loss of response to the drug. Concomitant immunosuppression with AZA, 6-MP, or MTX was able to prevent the formation of ATI.

It is recommended that infliximab-treated patients be put on a concomitant immunosuppressive agent to reduce the risk of ATI formation and hence reduce the risk of infusion reactions and prolong the duration of response.

There have been several attempts to explain the lack of response observed in about $30 \%$ of patients, varying from studies investigating clinical characteristics, ${ }^{119,120}$ (auto) antibodies, ${ }^{121,122}$ and genetic polymorphisms. ${ }^{121,123,124}$
In a study on $226 \mathrm{CD}$ patients, the response rate was significantly higher in patients with elevated CRP $(>5 \mathrm{mg} / \mathrm{l})$ than in patients with normal CRP values $(<5 \mathrm{mg} / \mathrm{l})$ before treatment ( $76 \%$ versus $46 \%$ ), suggesting that response was associated with higher systemic inflammation. ${ }^{125}$ The only replicated predictor of response so far has been the concomitant use of an immunosuppressive. ${ }^{119,120}$

\section{CDP57I}

CDP571 is a humanized IgG4 anti-TNF- $\alpha$ antibody with 95\% human and 5\% murine protein, that is administered intravenously. and has been studied in active CD. A phase II dosefinding trial demonstrated the short term benefit of CDP571 $10 \mathrm{mg} / \mathrm{kg}$ for inducing a clinical response at two weeks in patients with active CD. ${ }^{126} \mathrm{~A}$ phase III trial of CDP571 $10 \mathrm{mg} / \mathrm{kg}$ again showed short-term benefit for inducing clinical response at two weeks in patients with active CD but no significant difference at 28 weeks with maintenance dosing every eight weeks. ${ }^{127}$ A post-hoc analysis of a subgroup of patients with CRP concentrations $\geq 10 \mathrm{mg} / \mathrm{l}$ demonstrated significantly increased response rates for CDP571 $10 \mathrm{mg} / \mathrm{kg}$ at both two weeks and 28 weeks. Two controlled trials failed to demonstrate a steroid sparing benefit of CDP571 in patients with steroid-dependent CD. ${ }^{128}$ From these results, CDP571 was considered to be safe but not as effective as infliximab and further clinical development of CDP571 for the treatment of CD has been discontinued.

\section{Certolizumab pegol}

Certolizumab pegol (CZP) is a humanized TNF- $\alpha$ Fab' monoclonal antibody fragment linked to polyethylene glycol that is administered subcutaneously. The PEGylation increases the plasma half life of CZP to approximately two weeks, but it is unlikely to induce in vivo apoptosis. A large double-bind, placebo-controlled phase III trial, the PRECISE program, is composed by four studies (PRECISE 1, 2, 3, 4). PRECISE 3 and 4 are ongoing as part of the WELCOME study, designed to examine the effects of CZP in patients failing or intolerant to infliximab.

In the PRECISE $1,{ }^{129} 662$ patients with moderate to severe CD were stratified according to baseline levels of CRP and were randomly assigned to receive either $400 \mathrm{mg}$ of CZP or placebo subcutaneously at weeks $0,2,4$, and then every four weeks. Primary end points were the induction of a response at week 6 and a response at both weeks 6 and 26. Among patients with a baseline CRP level of at least $10 \mathrm{mg} / 1,37 \%$ of patients in the CZP group had a response at week 6, as compared with $26 \%$ in the placebo group. At both weeks 6 and 26, 
the corresponding values were $22 \%$ and $12 \%$, respectively. In the overall population, response rates at week 6 were $35 \%$ in CZP group and 27\% in the placebo group; at both week 6 and 26 the response rates were $23 \%$ and $16 \%$, respectively. At weeks 6 and 26, the rates of remission in the two groups did not differ significantly. Serious adverse events were 10\% in CZP group, compared to $7 \%$ in the placebo group. This study showed that induction and maintenance therapy with CZP was associated with a modest improvement in response rates, compared to placebo, but with no significant improvement in remission rates.

Design of the study was different in the PRECISE 2:130 as induction therapy, $400 \mathrm{mg}$ of CZP was administered subcutaneously at weeks 0,2 , and 4 . Patients with a clinical response (CDAI reduction of at least 100 from baseline) at week 6 were randomly assigned to receive $400 \mathrm{mg}$ of CZP or placebo every four weeks through week 24 with follow up through week 26.

At week 6, 64\% of patients achieved a clinical response that was maintained through week 26 in $62 \%$ of patients with a baseline CRP level of at least $10 \mathrm{mg} / \mathrm{l}$ who were receiving CZP (versus $34 \%$ of those receiving placebo) and in $63 \%$ of patients in intention-to-treat population who were receiving CZP (versus 36\% receiving placebo). Among patients with a response at week 6 , remission (reduction of CDAI at least 150 ) at week 26 was achieved in $48 \%$ of CZP patients and in $29 \%$ of placebo group. Serious adverse events (including one case of pulmonary tuberculosis) occurred in 3\% of patients receiving $\mathrm{CZP}$ and less than $1 \%$ of patients receiving placebo.

In conclusion, the patients with a response to induction therapy with CZP were more likely to have a maintained response and a remission at week 26 with CZP treatment than with placebo.

Actually, CZP is available for clinical use in CD in USA but not in Europe. Results from ongoing studies are eagerly awaited.

\section{RDP58}

RDP58 is a novel anti-inflammatory decapeptide able to block TNF production at a post-transcriptional step, ${ }^{131}$ and also inhibits production of IFN- $\gamma$, IL-2, and IL-12. RDP58 has been shown to be effective in murine and primate models of colitis. ${ }^{132,133}$ In a phase II study, ${ }^{134} 127$ patients with mild-to-moderate active UC were randomized to receive placebo or an oral solution of RDP58 at 100, 200, or $300 \mathrm{mg}$ daily for 28 days. Clinical remission was achieved in $72 \%$ of patients in the 300-mg group, 70\% in the 200-mg group,
$29 \%$ in the $100-\mathrm{mg}$ group, and $40 \%$ in the placebo group, with response rates of $72 \%, 77 \%, 33 \%$, and $44 \%$, respectively. There were no differences in adverse events among any of the treatment groups compared with placebo.

Studies in $\mathrm{CD}$ have also begun and results from future trials are awaited.

\section{Etanercept}

Etanercept is a genetically engineered fusion protein consisting of two recombinant human TNF p75 receptors linked to an Fc portion of human IgG1 fragment. The subcutaneous injection of etanercept at the dose of $25 \mathrm{mg}$ twice weekly, which is an effective dose for rheumatoid arthritis, is a safe but ineffective dose for the treatment of patients with moderate to severe CD. ${ }^{135}$

\section{Onercept}

Onercept is a fully human recombinant soluble TNF p55 receptor administered subcutaneously. A pilot study of onercept in patients with active $\mathrm{CD}$ showed benefit at higher dose. ${ }^{136}$ A large, placebo-controlled, dose-finding study on 207 patients with active CD showed a safe profile but onercept was no effective at the doses studied for CD patients. ${ }^{137}$

\section{Adalimumab}

Adalimumab (ADA) is a fully human IgG1 monoclonal antibody to TNF- $\alpha$ that is administered subcutaneously. An uncontrolled pilot study demonstrated that adalimumab was well tolerated in patients with CD who lost response, or developed infusion reactions or delayed-type hypersensitivity reactions to infliximab. ${ }^{138}$ In the CLASSIC $1^{139}$ trial 299 infliximab-naïve patients with active CD were treated with adalimumab. An induction dose of $160 \mathrm{mg}$ followed by $80 \mathrm{mg}$ at week 2 achieved remission in $36 \%$ at week 4 (versus $12 \%$ placebo). In the CLASSIC II ${ }^{140}$ trial, 276 patients enrolled in CLASSIC I received open-label ADA at week 0 and 2; 55 patients in remission at both weeks 0 and 4 were re-randomized to ADA $40 \mathrm{mg}$ every other week, $40 \mathrm{mg}$ weekly or placebo for 56 weeks. At week $5679 \%$ of patients who received ADA $40 \mathrm{mg}$ every other week and $83 \%$ who received $40 \mathrm{mg}$ weekly were in remission, compared with $44 \%$ for placebo group.

In the $\mathrm{CHARM}^{141}$ trial, patients received open-label induction therapy with ADA $80 \mathrm{mg}$ at week 0 , followed by $40 \mathrm{mg}$ at week 2 . At week 4 , patients were stratified by response and randomized to double-bind treatment with placebo, ADA $40 \mathrm{mg}$ every other week or ADA $40 \mathrm{mg}$ weekly through week 56 . The percentage of randomized responders in remission was significantly greater in the ADA $40 \mathrm{mg}$ 
every other week and $40 \mathrm{mg}$ weekly groups vs placebo at week 26 (40\%, 47\% and 17\%, respectively) and week 56 (36\%, 41\%, and $12 \%$, respectively).

In all studies adalimumab was well tolerated, with a safety profile consistent with previous experience with the drug. Adalimumab is available for clinical use in patients with CD refractory to conventional therapy. Studies in UC are currently ongoing.

\section{Inhibitors of proinflammatory cytokine receptors}

\section{Anti IL-6R}

A humanized monoclonal antibody against IL-6R (MRA) has been developed, and its efficacy in the treatment of active CD was reported. ${ }^{142}$ Thirty-six patients with active $\mathrm{CD}$ refractory to conventional therapies were randomized to receive biweekly infusions of MRA or placebo, or an alternate MRA/placebo (every-4th-week MRA) regimen for 12 weeks at $8 \mathrm{mg} / \mathrm{Kg}$. The response and remission rates in the MRA biweekly infusion group were significantly higher than in the placebo group ( $80 \%$ vs $31 \%$; $20 \%$ vs $0 \%$, respectively); however, the clinical response of the every-4th-week regimen was only $42 \%$. Infusions were well tolerated and, although promising, these preliminary data will need confirmation from larger trials.

\section{Inhibitors of ThI polarization and proliferation}

\section{Anti-IL-2 receptor (CD25) antibodies (daclizumab and basiliximab)}

Daclizumab is a recombinant humanized IgG1 monoclonal antibody to IL-2 receptor (CD25), which blocks the binding of IL-2 to the IL-2 receptor. An open label pilot study of daclizumab suggested that it was beneficial for patients with active UC. ${ }^{143}$ However, a recent placebo-controlled phase II trial of daclizumab at intravenous doses of $1 \mathrm{mg} / \mathrm{kg}$ twice with a four-week interval or $2 \mathrm{mg} / \mathrm{kg}$ every second week for a total of four doses in 159 patients with active UC failed to show any efficacy. ${ }^{144}$

A recent open-label, pilot trial evaluated the efficacy of a chimeric monoclonal anti-CD25 antibody, basiliximab, as a steroid-sensitizing agent in steroid-resistant UC. ${ }^{145}$ Fifteen patients received basiliximab intravenously in addition to their standard steroid treatment and $80 \%$ achieved remission within six weeks. A large study, placebo controlled is required.

\section{Anti-IL-I2}

In a multicentric, randomized, placebo-controlled, doubleblind, phase II clinical trial, ${ }^{146}$ the safety and efficacy of a human monoclonal antibody against IL-12 was evaluated in 79 patients with active CD. Patients were randomly assigned to receive seven weekly subcutaneously injections of $1 \mathrm{mg} / \mathrm{kg}$ or $3 \mathrm{mg} / \mathrm{kg}$ of anti-IL-12 or placebo, with either a four-week interval between the first and second injection (Cohort 1) or no interruption between the two injections (Cohort 2). Safety was the primary end point, and rates of clinical response (defined by a reduction in CDAI of at least 100 points) and remission (CDAI score of 150 or less) were secondary endpoints. Seven weeks of uninterrupted treatment with $3 \mathrm{mg} / \mathrm{kg}$ of anti-IL-12 resulted in higher response rates than did placebo administration (75\% vs $25 \%$ ). At 18 weeks of follow-up, the difference in response rates was no longer significant (69\% vs 25\%). Differences in remission rates between the group given $3 \mathrm{mg} / \mathrm{kg}$ and the placebo group in the Cohort 2 were not significant at the end of treatment or at the end of follow-up (38\% and $0 \%$, respectively, at both times). There were no significant differences in response rates among the groups in Cohort 1. The rates of adverse events among patients receiving antiIL-12 were similar to those among patients given placebo, except for a higher rate of local reactions at injection sites in the former group.

\section{Anti-IFN- $\gamma$ (Fontolizumab)}

Fontolizumab is a humanized monoclonal antibody to IFN- $\gamma$. In a phase I/II dose escalation study, ${ }^{147} 28$ patients with moderate-to-severe active $\mathrm{CD}$ were randomized to receive a single infusion of $\mathrm{HuZAF}$, a humanized anti-IFN- $\gamma$ monoclonal antibody, at $0.1 \mathrm{mg} / \mathrm{kg}, 1 \mathrm{mg} / \mathrm{kg}$, or $4 \mathrm{mg} / \mathrm{kg}$, or placebo. A dose-dependent effect was seen, with the highest response and remission rates achieved in the 4-mg group ( $86 \%$ vs $50 \%$ and $71 \%$ vs $33 \%$, respectively). HuZAF was well tolerated, with a good safety profile. The results of a larger, double-blind, placebo-controlled study of fontolizumab in patients with moderate-to-severe CD were reported. ${ }^{148}$ In this study 133 patients with CDAI scores between 250 and 450 were randomized to receive placebo or $4 \mathrm{mg} / \mathrm{kg}$ or $10 \mathrm{mg} / \mathrm{kg}$ fontolizumab. The first 42 patients received a single treatment; the subsequent 91 patients received two infusions (days 0 and 28). Fontolizumab had a beneficial effect on disease activity in patients who received two infusions of drug. This effect was most prominent in patients with objective evidence of inflammation as defined by an elevated concentration of CRP. Safety and tolerability were good, but more information on long-term data, follow-up and duration of remission are needed to define correctly its safety profile. 


\section{Adhesion molecule inhibitors}

\section{Natalizumab}

Natalizumab is a recombinant, humanized IgG4 monoclonal antibody against $\alpha_{4}$ integrin. It inhibits both $\alpha_{4} \beta_{7}$ integrin/ MAdCAM-1 interaction and $\alpha_{4} \beta_{1} /$ VCAM- 1 binding.

Two phase II studies of intravenous natalizumab at doses of $3 \mathrm{mg} / \mathrm{kg}, 3 \mathrm{mg} / \mathrm{kg}$ every four weeks $\times 2$ doses, and $6 \mathrm{mg} / \mathrm{kg}$ every 4 weeks $\times 2$ doses showed significant short-term benefit for natalizumab in patients with active $\mathrm{CD} .{ }^{149,150} \mathrm{~A}$ large phase III study in patients with active CD failed to show a benefit for natalizumab $300 \mathrm{mg}$ every four weeks $\times 3$ doses, primarily due to an unexpectedly high placebo response rate. ${ }^{151}$ A post hoc exploratory analysis of a subgroup of patients with elevated CRP concentrations above the normal range demonstrated a significant effect for natalizumab compared with placebo. ${ }^{151}$ Patients who responded to natalizumab in the phase III induction study were re-randomized to maintenance therapy with natalizumab $300 \mathrm{mg}$ or placebo every four weeks up to six months (natalizumab withdrawal study). This maintenance study demonstrated a highly significant maintenance benefit, with the difference between the treatment groups at six months exceeding $30 \% .{ }^{152}$ Recently, the ability to taper or discontinue oral corticosteroids in patients treated with natalizumab, was evaluated in a randomized, double-blind, placebo-controlled, multicentric study (ENACT-2). ${ }^{153}$ The results of this study demonstrated that natalizumab seems to be associated with steroid-sparing effects in patients with $\mathrm{CD}$ as evidenced by the ability of the drug to sustain clinical response and/or remission over time following the withdrawal of concomitant corticosteroids.

Natalizumab $3 \mathrm{mg} / \mathrm{kg}$ e.v. has also demonstrated some evidence of clinical benefit at two weeks post-infusion in an uncontrolled study in patients with active UC..$^{154}$

Although these promising results, due to the report of two cases of polymyeloleukodystrophy (PML) in two patients receiving concomitant natalizumab and beta interferon. PML, which almost invariably occurs in patients with AIDS or leukemia or in organ-transplant recipients, is a fatal opportunistic infection of the central nervous system caused by reactivation of a clinically latent JC polyomavirus infection. The drug which was recently marketed for multiple sclerosis has been taken off the market but recently is re-marketed in USA also for $\mathrm{CD}$ with a lot of safety recommendations.

\section{MLN-02}

MLN-02 is a humanized immunoglobulin G1 (IgG1) monoclonal antibody against $\alpha_{4} \beta_{7}$ integrin that selectively inhibits leukocyte adhesion in the gastrointestinal mucosa.
Fc receptor recognition and binding has been detected, thus eliminating complement fixation and cytokine release.

A randomized placebo-controlled trail ${ }^{155} 185$ patients with mild to moderately active $\mathrm{CD}$ were randomized to receive MLN-02 $(0.5$ or $2.0 \mathrm{mg} / \mathrm{kg})$ or placebo on days 1 and 29. At 2 months, neither treatment group achieved the primary endpoint, which was a statistically significant difference from placebo in achieving clinical response (decrease of $>70$ points in CDAI score). There was a statistically significant difference seen between the $2.0-\mathrm{mg} / \mathrm{kg}$ and placebo groups (36.9\% vs $20.7 \%$ ) in achieving the secondary end point of clinical remission (CDAI score $<150$ ), and there was a trend toward dose response. The adverse events (nausea and nasopharyngitis) were more frequent in the MLN-02 treatment groups, but no patients discontinued the treatment.

A phase I/II, double-blind, placebo-controlled, ascendingdose trial examined the safety and pharmacology of MLN-02 in 28 patients with moderately severe UC. ${ }^{156}$ Patients received a single dose of $0.15 \mathrm{mg} / \mathrm{kg}$ MLN-02 s.c., a single dose of 0.15 . 0.5 , or $2.0 \mathrm{mg} / \mathrm{kg}$ e.v. (groups $1-4$ ), or placebo. A meaningful endoscopic response (defined as 2-grade improvement) was observed in $1 / 5,0 / 5,3 / 5$, and $1 / 5$ patients in groups $1-4$, respectively, compared to $2 / 8$ patients in the placebo group. In group 3, $40 \%$ of patients $(0.5 \mathrm{mg} / \mathrm{kg}$ MLN-02) had complete endoscopic remission (defined as modified Baron's score of 0 ) and clinical remission (defined as a Mayo Clinic Score of 0). MLN-02 appears to be a generally well-tolerated and effective therapy especially for active UC, but further trials are necessary to confirm the efficacy of the drug in IBD.

\section{Alicaforsen (ISIS 2302)}

The interaction of lymphocyte-associated $\alpha_{1} \beta_{2}$-integrin, also known as leukocyte function antigen (LFA)-1, and its ligand, intercellular adhesion molecule-1 (ICAM-1), is important for the recruitment of leukocytes to inflammatory sites. ISIS 2302, a 20-base phosphorothioate antisense oligodeoxynucleotide, is designed to hybridize to a 3' untranslated region of human ICAM-1 messenger ribonucleic acid (mRNA). The heterodimer formed is cleaved by ubiquitous ribonuclease $\mathrm{H}$, resulting in a reduction in ICAM-1 protein expression. ${ }^{157}$

Initial positive results were reported in a pilot trial, ${ }^{158}$ but two subsequent placebo-controlled trials failed to demonstrate efficacy. The first involved 75 patients treated with subcutaneous ISIS $23020.5 \mathrm{mg} / \mathrm{kg}$ for durations of two days, one week, two weeks, four weeks, or placebo, and only 3.3\% reached steroid-free remission at week $14 .{ }^{159}$ The second randomized 299 patients to receive intravenous ISIS 2302 
at $2 \mathrm{mg} / \mathrm{kg}$ (three times weekly) for two or four weeks, or placebo. ${ }^{160}$ Although steroid-free remission rates were similar to those of the placebo group, pharmacodynamic analysis revealed a significant relationship between drug exposure and response, which suggests that ISIS 2302 might have been effective when if given in adequate doses.

ISIS 2302 in enema formulation showed significant improvement in 40 patients with distal UC in a randomized, placebo-controlled trial. ${ }^{161}$

\section{Growth hormone and growth factors}

Human growth hormone and a variety of growth factors such as TGF- $\beta$, which is secreted by Th3 cells and provides negative feedback on the differentiation of naïve $\mathrm{T}$ helper cells to Th1 or Th2 subtypes, epidermal growth factor (EGF), and keratinocyte growth factor-1 (KGF-1), may play an important role in IBD, ${ }^{162}$ for their potential use to heal and restore mucosal integrity.

\section{Human growth hormone}

Human growth hormone is a regulatory peptide that increases aminoacid and electrolyte uptake by the intestine, decreases intestinal permeability, and induces the expression of insulinlike growth factor I, which in turn stimulates collagen synthesis. The rationale for the use of growth hormone in $\mathrm{CD}$ is to reverse the catabolic process associated with inflammation. In the only placebo-controlled trial, ${ }^{163}$ a significant decrease in the CDAI score among 37 patients with moderate-to-severe $\mathrm{CD}$ who received subcutaneous growth hormone for four months, compared with placebo (143 \pm 144 vs $19 \pm 63)$, was demonstrated. However, the proportion of patients entering remission was not reported. Further controlled trials using the more conventional endpoints of improvement and remission are required.

\section{Epidermal growth factor}

Epidermal growth factor is a potent mitogenic peptide produced by salivary and duodenal Brunner's glands which stimulates cell proliferation in the gastrointestinal tract. A phase II study of recombinant epidermal growth factor enemas demonstrated efficacy in patients with active distal UC. ${ }^{164}$ Further trials are needed to confirm these impressive results. Moreover and most importantly, of concern is the potential for malignant transformation with EGF therapy in UC patients, because it upregulates the expression of protoncogens in patients with known cancer risk.

\section{Sargramostim and filgrastim}

Sargramostim (recombinant human granulocyte-macrophage colony stimulating factor) and filgrastim (recombinant human granulocyte colony stimulating factor) are hematopoietic growth factors that stimulate cells of the innate immune system, including neutrophils, macrophages, and dendritic cells. They have been shown to be effective in the treatment of genetic syndromes resulting in neutrophil dysfunction such as glycogen storage diseases, Chediak-Higashi syndrome, and chronic granulomatous disease similar to CD. ${ }^{165,166}$ Based on these observations, phase II trials were performed in patients with $\mathrm{CD}$, and suggested that sargramostim and filgrastim may be of benefit in patients with active and fistulizing $\mathrm{CD}$, possibly via an immunostimulant effect on neutrophils. ${ }^{167,168}$ In a randomized, double-blind, placebocontrolled trial, ${ }^{169} 124$ patients with moderately-to-severely active $\mathrm{CD}$ (CDAI $\geq 220$ and $\leq 475$ points) were treated with $6 \mu \mathrm{g} / \mathrm{kg} /$ day sargramostim or placebo subcutaneously for 56 days.

At end of this treatment period, significantly more sargramostim than placebo patients showed $\mathrm{a} \geq 100$-point response (48\% vs 26\%) and clinical remission (40\% vs 19\%).

\section{Conclusions:The state of art biologic agents in IBD}

Biologic agents are facing expanding indications in IBD and will undoubtedly benefit patients in the long-term. Infliximab has a clear high efficacy when administered early in the disease course, but more data are needed before it is positioned as a first-line therapy. Infliximab still needs to be administred intravenously and provides neither cure nor a durable effect after discontinuation.

The novel anti-TNF antibodies adalimumab and certolizumab pegol offer the perspective of subcutaneous out-of-hospital treatment. However both agents still have to stand up to the real world test of long-term therapy in a large patient population. The risk-benefit ratio for a powerful drug such as infliximab carries a limited risk of increased infections and possibly of lymphoma, particularly in combination with steroids and/or azathioprine.

With increasing knowledge about the pathogenesis of IBD and the mechanism driving the uncontrolled inflammation, new agents have entered the arena. The selective adhesion molecule inhibitor, natalizumab, is now approved for CD in the USA, but development has been temporarily discontinued due to unexpected JC virus brain infections. With anti-IL-12 and anti-IFN- $\gamma$ we are moving closer to the epicenter of immune reaction. This may result in higher 
efficacy, but also may raise new safety issues that should be monitored closely.

With recombinant GM-CSF, sargramostim, first attempts at boosting the innate immune system are being made. Therefore, it is likely to be only a pioneering agent that may provide the proof of concept only to be succeeded by more selective agents targeted at the immune innate system. Only agents restoring $\mathrm{T}$ cell tolerance long term or repairing the basic dysfunction in the innate immune system may provide the perspective of cure in chronically remitting and flaring diseases such as IBD. In conclusion, unmet needs for medical treatment include: primary nonresponse to infliximab, secondary loss of response to infliximab in $\mathrm{CD}$ and UC and long-term fistula healing in CD. Novel biologic treatments will probably be able to meet most of these needs, but combination therapy and tailoring of the management to the profile of the patient will most likely be necessary.

\section{Disclosure}

The authors report no conflicts of interest in this work.

\section{References}

1. van Assche G. Emerging drugs to treat Crohn's disease. Expert Opin Emerging Drugs. 2007;12:49-59.

2. Hanauer SB, Present DH. The state of the art in the management of inflammatory bowel disease. Rev Gastroenterol Disord. 2003;3:81-92.

3. Hanauer SB, Sandborn WJ. Practice Parameters Committee of the American College of Gastroenterology. Management of Crohn's disease in adults. Am J Gastroenterol. 2001;96:635-643.

4. Sandborn WJ, Feagan BG. Review article: mild to moderate Crohn's disease- defining the basis for a new treatment algorithm. Aliment Pharmacol Ther. 2003;18:263-277.

5. Camma' C, Giunta M, Rosselli M, et al. Mesalamine in the maintenance treatment of Crohn's disease: a meta-analysis adjusted for confounding variables. Gastroenterology. 1997;113:1465-1473.

6. Lochs H, Mayer M, Fleig WE, et al. Prophylaxis of postoperative relapse in Crohn's disease: European Cooperative Crohn's Disease Study VI. Gastroenterology. 2000;18:264-273.

7. Stein RB, Hanauer SB. Medical therapy for inflammatory bowel disease. Gastroenterol Clin North Am. 1999;28:297-321.

8. Faubion WA Jr, Loftus EV Jr, Harmsen WS, et al. The natural history of corticosteroid therapy for inflammatory bowel disease: a populationbased study. Gastroenterology. 2001;123:255-260.

9. Ardizzone S, Molteni P, Imbesi V, et al. Azathioprine in steroiddependent ulcerative colitis. J Clin Gastroenterol. 1997;26:330-333.

10. Ardizzone S, Samolvico F, Bollani S, et al. Azathioprine is more effective than oral 5-ASA in the treatment of steroid-dependent ulcerative colitis. Gastroenterology. 2001;120:A127.

11. Pearson DC, May GR, Fick GH, et al. Azathiorprine and 6-mercaptopurine in Crohn's disease. A meta-analyisis. Ann Intern Med. 1995;123; 132-142.

12. Pearson DC, May GR, Fick GH, et al. Azathioprine for maintaining remission of Crohn's disease. Cochrane Database Syst Rev. 2000;2: CD000067.

13. D'Haens G, Lemmens L, Geboes K, et al. Intravenous cyclosporine versus intravenous corticosteroids as single therapy for severe attacks of ulcerative colitis. Gastroenterology. 2001;120:1323-1329.
14. Present DH, Meltzer SJ, Krumholz MP, et al. 6-Mercaptopurine in the management of inflammatory bowel disease: short- and long-term toxicity. Ann Intern Med. 1989;111:641-649.

15. Friedman S. General principles of medical therapy of inflammatory bowel disease. Gastroenterol Clin North Am. 2004;33:191-208.

16. Feagan BG, Rochon J, Fedorak RN, et al. Methotrexate for the treatment of Crohn's disease. The North American Crohn's Disease Study Group Investigators. N Engl J Med. 1995;332:292-297.

17. Feagan BG, Fedorak RN, Irvine EJ, et al. A comparison of methotrexate with placebo for the maintenance of remission in Crohn's disease. North American Crohn's Disease Study Group Investigators. N Engl J Med. 2000;342:1627-1632.

18. Ardizzone S, Bollani S, Manzionna G, et al. Inflammatory bowel disease approaching the 3rd millennium: pathogenesis and therapeutic implications? Eur J Gastroenterol Hepatol. 1999;11:27-32.

19. Fiocchi C. Inflammatory bowel disease: etiology and pathogenesis. Gastroenterology. 1998;115:182-205.

20. Lim W-C, Hanauer SB. Emerging biologics therapies in inflammatory bowel disease. Rev Gastroenterol Disord. 2004;4:66-85.

21. Laroux FS, Pavlik KP, Wolf RE, et al. Dysregulation of intestinal mucosal immunity: implications in inflammatory bowel disease. News Physiol Sci. 2001;16:272-277.

22. Hugot JP, Chamaillard M, Zouali H, et al. Association of NOD2 leucine-rich repeat variants with susceptibility to Crohn's disease. Nature. 2001;411:599-603.

23. Ogura $\mathrm{Y}$, Bonen DK, Inohara N, et al. A frameshift mutation in NOD2 associated with susceptibility to Crohn's disease. Nature. 2001;411:603-606.

24. van Heel DA, McGovern DPB, Jewell DP. Crohn's disease: genetic susceptibility, bacteria, and innate immunity. Lancet. 2001;357:1902-1904.

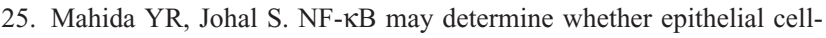
microbial interactions in the intestine are hostile or friendly. Clin Exp Immunol. 2001;123:347-349.

26. Beutler B. Autoimmunity and apoptosis: the Crohn's connection. Immunity. 2001;15:5-14

27. Weersma RK, Strokkers PC, van Bodegraven AA, et al. Molecular prediction of risk and severity in a large Dutch Crohn's disease cohort. Gut. 2008; Sept 29. Epub ahead of print.

28. Shanahan F. Crohn's disease. Lancet. 2002;359:62-69.

29. Elliott DE, Urban Jr, Argo CK, et al. Does the failure to acquire helmintic parasites predispose to Crohn's disease? FASEB J. 2000;4:430-435.

30. Franceschi S, Panza E, La Vecchia C, et al. Non-specific inflammatory bowel disease and smoking. Am J Epidemiol. 1987;125:445-452.

31. Lindberg E, Tysk C, Anderson K, et al. Smoking and inflammatory bowel disease: a case control study. Gut. 1988;29:352-7.

32. Miller LG, Goldstein G, Murphy M, et al. Reversible alterations in immunoregulatory $\mathrm{T}$ cells in smoking: analysis by monoclonal antibodies and flow cytometry. Chest. 1982;82:526-529.

33. Srivastava ED, Barton JR, O'Mahony S. Smoking, humoral immunity, and ulcerative colitis. Gut. 1991;32:1016-1019.

34. Cope GF, Heatley RV, Kelleher JK. Smoking and colonic mucus in ulcerative colitis. BMJ. 1986;293:481.

35. Coulie B, Camilleri M, Bharucha AE, et al. Colonic motility in chronic ulcerative proctosigmoiditis and the effects of nicotine on colonic motility in patients and healthy subjects. Aliment Pharmacol Ther. 2001;15:653-663.

36. Madretsma S, Wolters LM, van Dijk JP. In-vivo effect of nicotine on cytokine production by human non-adherent mononuclear cells. Eur J Gastroenterol Hepatol. 1996;8:1017-1020.

37. Plevy S. The immunology of inflammatory bowel disease. Gastroenterol Clin North Am. 2002;31:77-92.

38. Goke M, Podolsky DK. Regulation of the mucosal epiothelial barrier. Baillieres Clin Gastroenterol. 1996;10:393-405.

39. Fabia R, ArRajab A, Andersson M-L, et al. Impairment of bacterial flora in human ulcerative colitis and experimental colitis in the rat. Digestion. 1993;54:248-255. 
40. Fuss IJ, Neurath M, Boirivant M, et al. Disparate CD4 $4^{+}$lamina propria (LP) lymphokine secretion profiles in inflammatory bowel disease. Crohn's disease LP cells manifest increased secretion of IFN-gamma, whereas ulcerative colitis LP cells manifest increased secretion of IL-5. J Immunol. 1996;157:1261-1270.

41. Farrell JR, Peppercorn MA. Ulcerative colitis. Lancet. 2002;359:331-340.

42. Sartor RB. Pathogenesis and immune mechanisms of chronic inflammatory bowel diseases. Am J Gastroenterol. 1997;92(12 Suppl):S5-11.

43. Duchmann R, May E, Heike M, et al. T cell specifity and cross reactivity towards enterobacteria, bacteroides, bifidobacterium, and antigens from resident intestinal flora in humans. Gut. 1999;44:812-818.

44. Schuppan D, Hahn EG. MMPs in the gut: inflammation hits the matrix. Gut. 2000;47:12-14.

45. Pender SL, Tickle SP, Docherty AJ, et al. A major role of matrix metalloproteinases in T cell injury in the gut. J Immunol. 1997;158:1582-1590.

46. Powrie F. T cells in inflammatory bowel disease: protective and pathogenic roles. Immunity. 1995;3:171-174.

47. Boirivant M, Marini M, Di Felice G, et al. Lamina propria T cell in Crohn's disease and other gastrointestinal inflammation show defective CD2 pathway-induced apoptosis. Gastroenterology. 1999;116:557-565.

48. Ina K, Itoh J, Fukushima K, et al. Resistance of Crohn's disease T cells to multiple apoptotic signals is associated with a Bcl-2/Bax mucosal imbalance. J Immunol. 1999;163:1081-1090.

49. Boirivant M, Pica R, De Maria R, et al. Stimulated human lamina propria $\mathrm{T}$ cells manifest enhanced Fas-mediated apoptosis. $J$ Clin Invest. 1996;98:2616-2622.

50. Ueyama H, Kiyohara T, Sawada N, et al. Fas ligand expression on lymphocytes in lesions of ulcerative colitis. Gut. 1998;43:48-53.

51. Kuhn R, Lohler J, Rennick D, et al. Interleukin-10-deficient mice develop chronic enterocolitis. Cell. 1993;75:263-274.

52. Gordon MS, McCaskill-Stevens WJ, Battiato LA, et al. A phase I trial of recombinant human interleukin-11 (neumega rhIl-11 growth factor) in women with breast cancer receiving chemotherapy. Blood. 1996;87:3615-3624.

53. Trepicchio WL, Bozza M, Pedneault G, et al. Recombinant human IL-11 attenuates the inflammatory response through down-regulation of proinflammatory cytokine release and nitric oxide production J Immunol. 1996;157:3627-3634.

54. Potten CS. Protection of the small intestine clonogenic stem cells from radiation-induced damage by pretreatment with interleukin 11 also increases murine survival time. Stem Cells. 1996;14:452-459.

55. Qiu BS, Pfeiffer CJ, Keith JC Jr. Protection by recombinant human interleukin-11 against experimental TNB-induced colitis in rats. Dig Dis Sci. 1996;41:1625-1630.

56. Keith JC Jr, Albert LM, Ferranti TJ, et al. Recombinant human interleukin-11 (rhIL-11) decreases inflammatory bowel disease in HLA-B27 transgenic rats (abstr). Gastroenterology. 1995;108:A846.

57. Ardizzone S, Bianchi Porro G. Inflammatory bowel disease: new insights into pathogenesis and therapy. $J$ Intern Med. 2002;252:475-496.

58. Neurath MF, Fuss I, Kelsall BL, et al. Antibodies to interleukin 12 abrogate established experimental colitis in mice. J Exp Med. 1995; 182:1281-1290.

59. MacDonald TT, Monteleone G. Interleukin- 12 and Th1 immune responses in human Peyer's patches. Trends Immunol. 2001;22:244-247.

60. Pizarro TT, Michie MH, Bentz M, et al. IL-18, a novel immunoregulatory cytokine, is up-regulated in Crohn's disease: expression and localization in intestinal mucosal cells. J Immunol. 1999;162:6829-6835.

61. Siegmund B, Fantuzzi G, Rieder F, et al. Neutralization of interleukin18 reduces severity in murine colitis and intestinal IFN- $\gamma$ gamma and TNF-alpha production. Am J Physiol Regul Integr Comp Physiol. 2001;281:R1264-R1273.

62. Sartor RB. Cytokines in intestinal inflammation: pathophysiological and clinical considerations. Gastroenterology. 1994;106:533-539.

63. Amati L, Caradonna L, Jirillo E, et al. Immunological disorders in inflammatory bowel disease and immunotherapeutic implications. Ital J Gastroenterol Hepatol. 1999;31:313-325.
64. Papadakis CA, Targan SA. Tumor necrosis factor: biology and therapeutic inhibitors. Gastroenterology. 2000;119:1148-1157.

65. Blam ME, Stein RBS, Lichtenstein GR. Integrating anti-tumor necrosis factor therapy in inflammatory bowel disease: current and future perspectives. Am J Gastroenterol. 2001;96:1977-1997.

66. Lukacs NW, Chensue SW, Strieter RM, et al. Inflammatory granuloma formation is mediated by TNF-alpha-inducible intercellular adhesion molecule-1. J Immunol. 1994;152:5883-5889.

67. Alexopulou L, Pasparikis M, Kollias G. A murine transmembrane tumor necrosis factor (TNF) transgene induces arthritis by cooperative p55/p 75 TNF receptor signaling. Eur J Immunol. 1997;27:2588-2592.

68. van Deventer SJH. A place for TACE. Gut. 2002;51:5-6.

69. Moss ML, Jin SL, Milla ME. Cloning of a disintegrin metalloproteinase that processes precursor tumour-necrosis factor-alpha. Nature. 1997;385:733-735.

70. Black RA, Rauch CT, Kozlosky CJ. A metalloproteinase disintegrin that releases tumour-necrosis factor-alpha from cells. Nature. 1997;385:729-733.

71. Brynskov J, Foegh P, Pedersen G, et al. Tumour necrosis factor $\alpha$ converting enzyme (TACE) activity in the colonic mucosa of patients with inflammatory bowel disease. Gut. 2002;51:37-43.

72. Yamamoto M, Yoshozaki K, Kishimoto T, et al. IL-6 is required for the development of Th1 cell-mediated murine colitis. J Immunol. 2000; $164: 4878-4882$.

73. Atreya R, Mudter J, Finotto S, et al. Blockade of interleukin 6 trans signalling suppressor $\mathrm{T}$ cell resistance against apoptosis in chronic intestinal inflammation: evidence in Crohn's disease and experimental colitis in vivo. Nat Med. 2000;6:583-588.

74. Mangelsdorf DJ, Thummel C, Beato M. The nuclear receptor superfamily: The second decade. Cell. 1995;83:835-839.

75. Fajas L, Auboeuf D, Raspe E. The organization, promoter analysis, and expression of the human PPArgamma gene. J Biol Chem. 1997;272:19779-19789.

76. Butcher EC, Picker LJ. Lymphocyte homing and homeostasis. Science. 1996;272:60-66.

77. Sandborn WJ, Yednock TA. Novel approaches to treating inflammatory bowel disease: targeting alpha-4 integrin. Am J Gastroenterol. 2003;98:2372-2382

78. Sands BE. Biologic therapy for inflammatory bowel disease. Inflamm Bowel Dis. 1997;3:95-113.

79. Breedveld FC. Therapeutic monoclonal antibodies. Lancet. 2000;355: 735-740.

80. Delves PJ, Roitt IM. The immune system, Second of two parts. $N$ Engl J Med. 2000;343:108-117.

81. Dumont FJ. IDEC-131. IDEC/Eisai. Curr Opin Investig Drugs. 2002; 3:725-734

82. Danese S, Scaldaferri F, Vetrano A, et al. Critical role of CD40 CD40 ligand pathway in regulating mucosal inflammation- driven angiogenesis in inflammatory bowel disease. Gut. 2007;56:1248-1256.

83. Deusch K, Mauthe B, Reiter C, et al. CD4-antibody treatment of inflammatory bowel disease: one year follow-up. Gastroenterology. 1993;104:A691.

84. Stronkhorst A, Radema S, Yong SL, et al. CD4 antibody treatment in patients with active Crohn's disease: a phase I dose finding study. Gut. 1997;40:320-327.

85. Emmrich J, Seyfarth M, Fleig WE, et al. Treatment of inflammatory bowel disease with anti-CD4 monoclonal antibody. Lancet. 1991;338: 570-571.

86. Emmrich J, Seyfarth M, Liebe S, et al. Anti-CD6 antibody treatment in inflammatory bowel disease without a long $\mathrm{CD}^{+}$-cell depletion. Gastroenterology. 1995;108:A815.

87. Canva-Delcambre V, Jacquot S, Robinet E, et al. Treatment of severe Crohn's disease with anti-CD4 monoclonal antibody. Aliment Pharmacol Ther. 1996;10:721-727.

88. Kozuch PL, Hanauer SB. General principles and pharmacology of biologics in inflammatory bowel disease. Gastroenterol Clin $\mathrm{N} \mathrm{Am}$. 2006;35:757-773 
89. Plevy SE, Salzberg BA, Reguiero M, et al. A humanized anti-CD3 monoclonal antibody, visilizumab, for treatment of severe steroidrefractory ulcerative colitis: preliminary results of a phase I study. Gastroenterology. 2003;124:A7.

90. Plevy SE, Salzberg BA, Van Assche G. A phase I study of visilizumab, a humanized anti-CD3 monoclonal antibody, for treatment of severe steroid-refractory ulcerative colitis. Gastroenterology. 2007;133:1414-1422.

91. van Deventer SJ, Elson CO, Fedorak RN. Multiple doses of intravenous interleukin 10 in steroid-refractory Crohn's disease. Crohn's disease Study Group. Gastroenterology. 1997;113:383-392.

92. Schreiber S, Fedorak RN, Nielsen $\mathrm{OH}$, et al. Safety and efficacy of recombinant human interleukin 10 in chronic active Crohn's disease. Gastroenterology. 2000;119:1462-1472.

93. Fedorak RN, Gangl A, Elson CO, et al. Recombinant human interleukin 10 in the treatment of patients with mild to moderately active Crohn's disease. Gastroenterology. 2000;119:1473-1482.

94. Fedorak NR, Nielsen $\mathrm{OH}$, Williams NC, et al. Human recombinant interleukin-10 is safe and well tolerated but dose not induce remission in steroid dependent Crohn's disease. Gastroenterology. 2001;120:A127.

95. Schreiber S, Fedorak NR, Wild G, et al. Ulcerative Colitis IL-10 Cooperative Study Group. Safety and tolerance of rHuIL-10 treatment in patients with mild/moderate active ulcerative colitis. Gastroenterology. 1998;114:A1080-A1081.

96. Steidler L, Hans W, Schotte L, et al. Treatment of murine colitis by Lactococcus lactis secreting interleukin-10. Science. 2000;289:1352-1355.

97. Sands BE, Bank S, Sninsky CA, et al. Preliminary evaluation of safety and activity of recombinant human interleukin 11 in patients with active Crohn's disease. Gastroenterology. 1999;117:58-64.

98. Sands BE, Winston B, Salzberg B, et al. Randomized, controlled trial of recombinant human interleukin 11 in patients with active Crohn's disease. Aliment Pharmacol Ther. 2002;16:399-406.

99. Herrlinger K, Witthoeft T, Raedler A, et al. Randomized, double-blind, double-blind, controlled trial of subcutaneous recombinant human interleukin-11 versus prednisolone in active Crohn's disease. Am J Gastroenterol. 2006;101:793-797.

100. Van Dullemen HM, van Deventer SJH, Hommes DW, et al. Treatment of Crohn's disease with anti-tumor necrosis factor chimeric monoclonal antibody (cA2). Gastroenterology. 1995;109:129-135.

101. McCabe RP, Woody J, van Deventer SJH, et al. A multicenter trial of cA2 anti-TNF chimeric monoclonal antibody in patients with active Crohn's disease. Gastroenterology. 1996;110:A962.

102. Targan SR, Hanauer SB, van Deventer SJH, et al. A short-term study of chimeric monoclonal antibody cA2 to tumor necrosis factor $\alpha$ for Crohn's disease. N Engl J Med. 1997;337:1029-1035.

103. Rutgeerts P, D'Haens G, Targan S, et al. Efficacy and safety or retreatment with anti-tumor necrosis factor antibody (Infliximab) to maintain remission in Crohn's disease. Gastroenterology. 1999;117:761-769.

104. Hanauer SB, Feagan BG, Lichtenstein GR, et al. Maintenance Infliximab for Crohn's disease: the ACCENT I randomised trial. Lancet. 2002:359: 1541-1549.

105. Rutgeerts P, Feagan BG, Lichtenstein GR, et al. Comparison of scheduled and episodic treatment strategies of infliximab in Crohn's disease. Gastroenterology. 2004;126:402-413.

106. Sands BE, Anderson FH, Bernstein CN, et al. Infliximab maintenance therapy for fistulizing Crohn's disease. $N \mathrm{Engl} \mathrm{J} \mathrm{Med.}$ 2004;350:876-885.

107. Chey WY, Hussain A, Ryan C, et al. Infliximab for refractory ulcerative colitis. Am J Gastroenterol. 2001;96:2373-2381.

108. Sands BE, Tremaine WJ, Sandborn WJ, et al. Infliximab in the treatment of severe, steroid-refractory ulcerative colitis: a pilot study. Inflamm Bowel Dis. 2001;7:83-88.

109. Rutgeerts P, Sandborn WJ, Feagan BG, et al. Infliximab for induction and maintenance therapy for ulcerative colitis. $N$ Engl J Med. 2005;353:2462-2476.
110. Gornet JM, Couve S, Hassani Z, et al. Infliximab for refractory ulcerative colitis or indeterminate colitis: an open-label multicentre study. Aliment Pharmacol Ther. 2003;18:175-181.

111. Papadakis KA, Treyzone L, Abreu MT, et al. Infliximab in the treatment of medically refractory indeterminate colitis. Aliment Pharmacol Ther. 2003;18:741-747.

112. Regueiro M, Valentine J, Plevy S, et al. Infliximab for treatment of pyoderma gangrenosum associated with inflammatory bowel disease. Am J Gastroenterol. 2003;98:1821-1826.

113. Lyons JL, Rosenbraun JT. Uveitis associated with inflammatory bowel disease compared with uveitis associated with spondyloarthropathy. Arch Ophthalmol. 1997;115:61-64.

114. Van den Bosch F, Kruithof E, De Vos M, et al. Crohn's disease associated with spondyloarthropathy: effect of anti-TNF-alpha blockade with infliximab on articular symptoms. Lancet. 2000;356:1821-1822.

115. Hommes DW, Baert F, Van Assche G, et al. Therapy management of recent onset Crohn's disease: A controlled, randomized trial comparing step-up and top-down therapy. Gastroenterology. 2005;129:371.

116. Sandborn WJ, Faubion WA. Biologics in inflammatory bowel disease: how much progress have we made? Gut. 2004;53:1366-1373.

117. Sarzi Puttini P, Ardizzone S, Manzionna G, et al. Infliximabinduced lupus in Crohn's disease: a case report. Dig Liver Dis. 2003;35:814-817.

118. Baert F, Noman M, Vermeire S, et al. Influence of immunogenecity on the long-term efficacy of infliximab in Cronh's disease. $N$ Engl J Med. 2003;348:601-608.

119. Parsi MA, Achkar JP, Richardson S, et al. Predictors of response to infliximab in patients with Crohn's disease. Gastroenterology. 2002;123:707-713.

120. Vermeire S, Louis E, Carbonez A, et al. Logistic regression of clinical parameters influencing response to infliximab. Am J Gastroenterol. 2002;97:2357-2363.

121. Taylor KD, Plevy SE, Yang H, et al. ANCA pattern and LTA aplotype relationship to clinical responses to anti-TNF antibody treatment in Crohn's disease. Gastroenterology. 2001;120:1347-1355.

122. Esters N, Vermeire S, Joossens S, et al. Belgian Group of Infliximab Expanded Access Program in Crohn's Disease. Serological markers for prediction of response to anti-tumor necrosis factor treatment in Crohn's disease. Am J Gastroenterol. 2002;97:1458-1462.

123. Vermeire S, Louis E, Rutgeerts P, et al. The NOD2 gene does not influence response to infliximab in Crohn's disease. Gastroenterology. 2002;123:106-111.

124. Mascheretti S, Hampe J, Croucher PJ, et al. Response to infliximab treatment in Crohn's disease is not associated with mutations in theCARD15 (NOD2) gene: an analysis in 534 patients from two multicenter, prospective GCP-level trials. Pharmacogenetics. 2002;12:509-512.

125. Louis E, Vermeire S, Rutgeerts $\mathrm{P}$, et al. A positive response to infliximab in Crohn's disease: association with higher systemic inflammation before treatment but not with $-308 \mathrm{TNF}$ gene polymorphism. Scand J Gastroenterol. 2002;37:818-824.

126. Sandborn WJ, Feagan BG, Hanauer SB, et al. An engineered human antibody to TNF (CDP571) for active Crohn's disease: a randomised, palcebo-controlled trial. Gastroenterology. 2001;120:1330-1338.

127. Sandborn WJ, Feagan BG, Radford-Smith G, et al. A randomized, placebo-controlled trial of CDP571, a humanized monoclonal antibody to TNF- $\alpha$, in patients with moderate to severe Crohn's disease. Gastroenterology. 2003;124:A61.

128. Feagan BG, Sandborn WJ, Baker J, et al. A randomized, double-blind, placebo-controlled trial of CDP571, or steroid sparing and maintenance of remission in patients with steroid-dependent Crohn's disease. Gastroenterology. 2000;118:A655.

129. Sandborn WJ, Feagan BG, Stoinov S, et al. PRECISE 1 Study Investigators. Certolizumab pegol for the treatment of Crohn's disease. N Engl J Med. 2007;357:228-238.

130. Schreiber S, Khaliq-Kareemi M, Lawrance IC, et al. Maintenance therapy with certolizumab pegol for Crohn's disease. $N$ Engl J Med. 2007;357:239-250. 
131. Iyer $\mathrm{S}$, Kontoyannis $\mathrm{D}$, Chevrier $\mathrm{D}$, et al. Inhibition of tumor necrosis factor mRNA translation by a rationally designed immunomodulatory peptide. J Biol Chem. 2000;275:17051-17057.

132. Murthy S, Flanigan A, Coppola D, et al. RDP58, a locally active TNF inhibitor, is effective in the dextran sulphate mouse model of chronic colitis. Inflamm Res. 2002;51:522-531.

133. Bourreille A, Doubremelle M, de la Bletiere DR, et al. RDP58, a novel immunomodulatory peptide with anti-inflammatory effects. A pharmacological study in trinitrobenzene sulphonic acid colitis and Crohn's disease. Scand J Gastroenetrol. 2003;38:526-532.

134. Travis SPL, Yap LM, Hawkey CJ, et al. RDP-58: novel and effective therapy, for ulcerative coltis: results of parallel, prospective, placebocontrolled trial. Am J Gastroenterol. 2003;98:S239.

135. Sandborn WJ, Hanauer SB, Katz S, et al. Etanercept for active Crohn's disease: A randomised, double-blind, placebo-controlled trial. Gastroenterology. 2001;121:1088-1094.

136. Rutgeerts P, Lemmens I, van Assche G, et al. Treatment of active Crohn's disease with onercept (recombinant human soluble p55 tumor necrosis factor receptor): results of a randomized, open-label, pilot study. Aliment Pharmacol Ther. 2003;17:185-192.

137. Rutgeerts P, Sandborn WJ, Fedorak RN, et al. Onercept for moderateto-severe-Crohn's disease: a randomized, double-bind, placebocontrolled trial. Clin Gastroenterol Hepatol. 2006;4:888-893.

138. Sandborn WJ, Hanauer SB, Loftus EV, et al. An open-label study of the human anti-TNF monoclonal antibody adalimumab subjects with prior loss of response or intolerance to infliximab for Crohn's disease. Am J Gastroenterol. 2004;99:1984-1989.

139. Hanauer SB, Sandborn WJ, Rutgeerts P, et al. Human anti-TNF monoclonal antibody (Adalimumab) in Crohn's disease: the CLASSIC I trial. Gastroenterology. 2006;130:323-333.

140. Sandborn WJ, Hanauer SB, Rutgeerts P, et al. Adalimumab for maintenence treatment of Crohn's disease: results of the CLASSIC II trial. Gut. 2007;56:1232-1239.

141. Colombel JF, Sandborn WJ, Rutgeerts P, et al. Adalimumab for maintenance of clinical response and remission in patients with Crohn's disease: the CHARM trial. Gastroenterology. 2007;132: $52-65$.

142. Ito H, Takazoe M, Fukuda Y, et al. Effective treatment of active Crohn's disease with humanized monoclonal antibody MRA to interleukin-6 receptor: a randomized plcebo-controlled trial. Gastroenterology. 2003;124:A25.

143. van Assche G, Dalle I, Noman M, et al. A pilot study on the use of the humanized anti-interleukin-2 receptor antibody daclizumab in active ulcerative colitis. Am J Gastroenetrol. 2003;98:369-376.

144. Van Assche G, Sandborn WJ, Feagan BG, et al. Daclizumab, a humanised monoclonal antibody to the interleukin 2 receptor (CD25), for the treatment of moderately to severely active ulcerative colitis: a randomised, double blind, placebo-controlled, dose ranging trial. Gut. 2006;55:1568-1574.

145. Creed TJ, Norman MR, Probert CS, et al. Basiliximab (anti-CD25) in combination with steroids may be an effective new treatment for steroid-resistant ulcerative colitis. Aliment Pharmacol Ther. 2003;18:1865-1875.

146. Mannon PJ, Fuss IJ, Mayer L, et al. Anti-interleukin-12 antibody for active Crohn's disease. N Engl J Med. 2004;35:2069-2079.

147. Rutgeerts P, Reinisch W, Colombel JF, et al. Preliminary results of a phase I/II study of Huzaf, an anti-IFN-monoclonal antibody, in patients with moderate to severe active Crohn's disease. Gastroenterology. 2002;122:A61

148. Van Assche G, Pearce T. Fontolizumab (Huzaftm), a humanized anti-IFN-gamma antibody, has clinical activity and excellent tolerability in moderate to severe Crohn's disease. Gut. 2004; 53(Suppl VI):A48.
149. Ghosh S, Goldin E, Gordon FH, et al. Natalizumab for active Crohn's disease. N Engl J Med. 2003;348:24-32.

150. Gordon FH, Lai CW, Hamilton MI, et al. A randomized placebocontrolled trial of a humanized monoclonal antibody to alpha4 integrin in active Crohn's disease. Gastroenterology. 2001;121:268-274.

151. Rutgeerts P, Colombel JF, Enns R, et al. Subanalysis from a phase 3 study on the evaluation of natalizumab in active Crohn's disease therapy-1 (ENACT-1). Gut. 2003;52(Suppl VI):A239.

152. Elan and Biogen Idec announce ANTEGREN-natalizumab-phase III maintenance trial in Crohn's disease met its primary endpoint. 2004. Accessed on Dec 3, 2008. Available from: htpp://www.elan.com.

153. Rutgeerts P, Enns R, Colombel JF, et al. 6-months steroid-sparing results of natalizumab in a controlled study of patients with Crohn's disease. Gut. 2004;53(Suppl VI):A48.

154. Gordon FH, Hamilton MI, Donoghue S, et al. A pilot study of treatment of active ulcerative colitis with natalizumab, a humanized monoclonal antibody to alpha-4 integrin. Aliment Pharmacol Ther. 2002;16:699-705.

155. Feagan BG, Greenberg G, Wild G, et al. Efficacy and safety of humanized alpha4 beta7 antibody in active Crohn's disease. Gastroenterology. 2003;124:A25.

156. Feagan BC, McDonald J, Greenberg G, et al. An ascending dose trial of a humanized A4B7 antibody in ulcerative colitis (UC). Gastroenterology. 2001;118:A874.

157. Bennet CF, Condon TP, Grimm S, et al. Inhibition of endothelial cell adhesion molecule expression with antisense oligonucleotides. J Immunol. 1994;152:3530-3540.

158. Yacyshyn BR, Bowen-Yacyshyn MB, et al. A placebo- controlled trial of ICAM-1 antisense oligonucleotide in the treatment of Crohn's disease. Gastroenterology. 1998;114:113-142.

159. Schreiber S, Nikolaus S, Malchow H, et al. Absence of efficacy of subcutaneous antisense ICAM-1 treatment of chronic active Crohn's disease. Gastroenterology. 2001;120:1339-1346.

160. Yacyshyn BR, Chey WY, Goff J, et al. Double-blind, placebo controlled trial of the remission inducing and steroid sparing properties of an ICAM-1 antisense oligodeoxynucleotide, alicaforsen (ISIS 2302), in active steroid dependent Crohn's disease. Gut. 2002;51:30-36.

161. Van Deventer SJ, Tami JA, Wedel MK. A randomised, controlled, double-bind, escalating dose study of alicaforsen enema in ulcerative colitis. Gut. 2004;53:1646-1651.

162. Beck PL, Podolsky DK. Growth factors in inflammatory bowel disease. Inflamm Bowel Dis. 1999;5:44-60.

163. Slonim AE, Bulone L, Damore MB, et al. A preliminary study of growth hormone therapy for Crohn's disease. $N$ Engl $J$ Med. 2000;342:1664-1666.

164. Sinha A, Nightgale J, West KP, et al. Epidermal growth factor enemas with oral mesalamine for mild-to-moderate left-sided ulcerative colitis or proctitis. N Engl J Med. 2003;349:350-357.

165. Korzenic JR, Dieckgraefe BK. Is Crohn's disease an immunodeficiency? A hypothesis suggesting possible early events in the pathogenesis of Crohn's disease. Dig Dis Sci. 2000;45:1121-1129.

166. Dieckgraefe BK, Korzenik JR, Husain A, et al. Association of glycogen storage disease $1 \mathrm{~b}$ and Crohn's disease: results of a North American survey. Eur J Pediatr. 2002;161(Suppl 1):S88-S92.

167. Dieckgraefe BK, Korzenik JR. Treatment of active Crohn's disease with recombinant human granulocyte-macrophage colony-stimulating factor. Lancet. 2002;360:1478-1480.

168. Korzenic JR. Dieckgraefe BK. Immunostimulation in Crohn's disease: results of a pilot study of G-CSF (R-Methug-CSF) in mucosal and fistulizing Crohn's disease. Gastroenterology. 2001;118:A874.

169. Korzenik J, Dieckgraefe B, Valentine J, et al. Sargramostim induces response and remission in patients with moderately-to-severely active Crohn's disease (CD): results from a randomized, double-blind, placebo-controlled trial. Gut. 2004;53(Suppl VI):A49. 
